
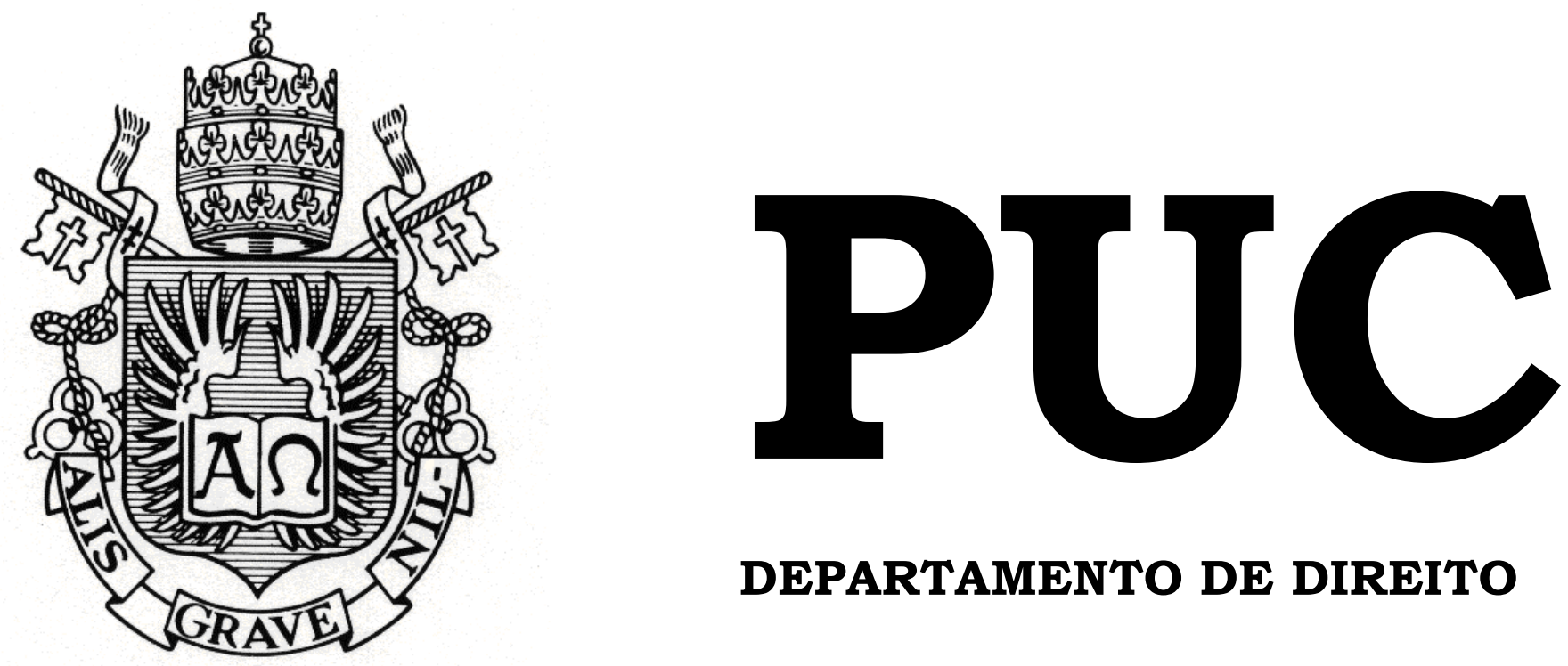

DEPARTAMENTO DE DIREITO

BULLYING ESCOLAR E A NECESSIDADE DE ATUAÇÃO CONJUNTA DE PAIS E EDUCADORES NO SEU COMBATE

por

MUSA MÁXIMO GOMES FERRAZ

ORIENTADOR: Caitlin Sampaio Mulholland

2011.1

PONTIFÍCIA UNIVERSIDADE CATÓLICA DO RIO DE JANEIRO

RUA MARQUÊS DE SÃO VICENTE, 225 - CEP 22453-900

RIO DE JANEIRO - BRASIL 


\title{
BULLYING ESCOLAR E A NECESSIDADE DE ATUAÇÃO CONJUNTA DE PAIS E EDUCADORES NO SEU COMBATE
}

\author{
por
}

MUSA MÁXIMO GOMES FERRAZ

\begin{abstract}
Monografia apresentada ao
Departamento de Direito da

Pontifícia Universidade Católica do

Rio de Janeiro (PUC-Rio) para a obtenção do Título de Bacharel em Direito.
\end{abstract}

Orientador(a): Caitlin Sampaio Mulholland. 


\section{AGRADECIMENTOS}

À minha mãe, Heloisa, agradeço pela dedicação, apoio e afeto costumeiros. Sem você, minha trajetória na PUC não teria sequer começado.

Ao meu pai, Ricardo, agradeço por ter despertado meu interesse no tema deste trabalho e por sempre me incentivar ao enriquecimento intelectual.

Aos meus irmãos, Inti e Ranti, agradeço pelo companheirismo fraternal.

Ao Gustavo Furini, agradeço pela paciência nos momentos de aflição e pelo suporte que me foi dado ao longo da elaboração desta monografia.

À Denise Chermont, agradeço pelo carinho e por ter me acompanhado desde o início de minha formação acadêmica.

À professora Caitlin Sampaio Mulholland, agradeço pela orientação e pelas sugestões.

Sem essas pessoas (algumas a quem talvez não tenha mencionado expressamente), estes passos iniciais da minha vida acadêmica certamente não teriam sido dados.

A todos, muito obrigada. 


\section{RESUMO}

Esta monografia trata do tema bullying no contexto escolar e do papel a ser desempenhado pelos pais e pelas instituições de ensino no combate a este tipo de violência escolar. Para entender o que é o bullying, será exposto o conceito deste termo, procurando diferenciá-lo das brincadeiras consideradas normais no ambiente escolar, bem como os sintomas demonstrados pelas crianças e jovens que estão envolvidos com essa prática, além das consequências psíquicas que podem advir da vitimização no bullying. Com isso, será possível munir o leitor de ferramentas capazes de auxiliar no diagnóstico do bullying, ajudando a romper as barreiras do silêncio que usualmente circundam esse fenômeno. Em seguida, será feita uma análise sobre a responsabilidade pelos atos de bullying praticados por menores no âmbito escolar, buscando evidenciar que o dever de vigilância imposto às instituições de ensino em relação aos educandos deve ser coordenado com o dever dos pais de educar seus filhos e de dirigir-lhes a conduta. É o que se pretende apontar, traçando, para tanto, um estudo da responsabilidade civil por fato de terceiro, abrangendo tanto a responsabilidade dos pais pelos atos dos filhos menores, quanto a responsabilidade das instituições de ensino pelos atos dos educandos, salientando os pressupostos para a caracterização de ambas. Dessa maneira, espera-se revelar as peculiaridades do bullying, enquanto uma prática definida pela repetitividade das agressões físicas e/ou psicológicas dirigidas pelo agressor contra a vítima, em uma relação desigual de poder, o que faz com que a escola, sozinha, não possa enfrentar a situação, sendo imprescindível a colaboração dos pais para o alcance de uma solução adequada para os casos de bullying escolar.

Palavras-chave: Bullying - Bullying escolar - Responsabilidade civil por fato de terceiro - Responsabilidade dos pais pelos atos dos filhos menores Responsabilidade das instituições de ensino pelos atos dos educandos Responsabilidade objetiva - $\quad$ Responsabilidade solidária. 


\section{SUMÁRIO}

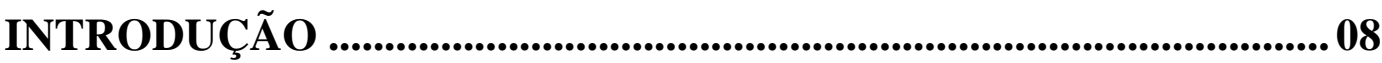

1. BULLYING ESCOLAR: IDENTIFICAÇÃO, INCIDÊNCIA NAS INSTITUIÇÕES BRASILEIRAS E ESTRATÉGIAS DE COMBATE .15

1.1. O Conceito de bullying ................................................................... 15

1.2. Bullying versus brincadeiras normais no ambiente escolar 18

1.3. Casos de violência motivados pelo bullying 20

1.4. Legislação e o bullying ................................................................227

1.5. Pesquisas sobre o bullying no Brasil........................................ 31

1.6. A judicialização dos conflitos na sociedade contemporânea e o bullying escolar........................................... 37

1.7. O comportamento dos envolvidos no bullying escolar e o papel dos adultos no seu diagnóstico.

1.8. Consequências psíquicas e comportamentais do bullying . 54

1.9. Os protagonistas do bullying escolar e a inserção do fenômeno no contexto da sociedade contemporânea .......... 55

1.10. Prevenção e soluções para o bullying escolar 63

2. A RESPONSABILIDADE DOS PAIS E DA INSTITUIÇÃO DE ENSINO PELOS ATOS DE BULLYING PRATICADOS POR MENORES NO ÂMBITO DAS ESCOLAS QUE ACARRETEM DANOS MORAIS E MATERIAIS ÀS VÍTIMAS 67 
2.1. O bullying é proibido pelo ordenamento jurídico brasileiro 67

2.2. A responsabilidade civil por fato de terceiro 69

2.2.1. A responsabilidade dos pais pelos atos dos filhos menores

2.2.1.1. Pressupostos da responsabilidade dos pais 78

2.2.2. A responsabilidade dos estabelecimentos de ensino pelos atos dos educandos 81

2.3. A responsabilidade das instituições de ensino no bullying escolar e a jurisprudência 84

2.4. O dever de indenizar dos pais dos agressores no bullying escolar e a jurisprudência 94

CONCLUSÃO. 102 


\section{ABREVIATURAS E SÍMBOLOS}

\begin{tabular}{|c|c|}
\hline Apud & 'Citado por' \\
\hline art. & Artigo \\
\hline $\mathrm{CC}$ & Código Civil \\
\hline $\mathrm{CDC}$ & Código de Defesa do Consumidor \\
\hline $\mathrm{CF}$ & Constituição Federal \\
\hline dez. & Dezembro \\
\hline $\mathrm{DF}$ & Distrito Federal \\
\hline ed. & Editora \\
\hline ECA & Estatuto da Criança e do Adolescente \\
\hline fev. & Fevereiro \\
\hline Ibid. & Ibidem ('mesmo autor e mesma obra') \\
\hline jul. & Julho \\
\hline MG & Minas Gerais \\
\hline Min. & Ministro \\
\hline $\mathrm{n}^{\mathrm{o}}$ & Número \\
\hline Op. Cit. & Opus citatum('na obra citada') \\
\hline ONG & Organização Não-Governamental \\
\hline p. & Página \\
\hline par & Parágrafo \\
\hline Rel. & Relator(a) \\
\hline
\end{tabular}




$\begin{array}{ll}\text { R\$ } & \text { Reais (moeda brasileira) } \\ \text { set. } & \text { Setembro } \\ \S & \text { Parágrafo } \\ \text { STJ } & \text { Superior Tribunal de Justiça } \\ \text { TJ/DFT } & \text { Tribunal de Justiça do Distrito Federal e Territórios } \\ \text { TJ/MG } & \text { Tribunal de Justiça de Minas Gerais } \\ \text { TJ/RJ } & \text { Tribunal de Justiça do Rio de Janeiro } \\ \text { TJ/RS } & \text { Tribunal de Justiça do Rio Grande do Sul }\end{array}$




\section{INTRODUÇÃO}

Testemunhamos diariamente, através dos noticiários ou de vivências próprias, a multiplicação e o aumento da intensidade dos comportamentos agressivos e transgressores na população infantojuvenil, colocando o tema bullying no centro dos debates da população em geral.

De fato, não raro nos deparamos com notícias nos jornais, matérias em programas de TV, vídeos na internet ou, ainda, filmes versando sobre o tema.

A hiperexposição do fenômeno na mídia contribuiu para aumentar as discussões sobre essa forma de violência na sociedade, de modo a levantar questionamentos tais como a definição do bullying, quem são os envolvidos nesta prática, quais valores prezados pela sociedade contemporânea são revelados pelas situações de bullying e, ainda, quem deve ser responsabilizado pelos atos de bullying praticados por menores.

No presente trabalho, limitaremo-nos a abordar o bullying no âmbito escolar, por parecer-nos que essa espécie possui maior riqueza de questões a serem tratadas, muito embora o bullying esteja presente em diversos contextos da vida diária, como no ambiente de trabalho ou em casa.

Episódios de verdadeiros massacres protagonizados por jovens no ambiente escolar, em todo o mundo, vêm sendo largamente divulgados pelos meios de comunicação.

O que não se sabia, até bem pouco tempo, é que a motivação da maior parte deles era o bullying sofrido por seus perpetradores, os quais decidiram vingar-se da perseguição que lhes era dirigida por seus colegas.

Mas, afinal, por que ocorre o bullying? Qual é o combustível para que essas condutas aconteçam em nossa sociedade? Por que as pessoas são perseguidas por serem "diferentes"? 
Ao contrário do que possa parecer, o bullying é um fenômeno tão antigo quanto a própria instituição escolar. Entretanto, embora ele sempre tenha existido nas escolas de todo o mundo, hoje tal prática ganha dimensões muito mais graves.

Assim, embora o bullying tenha estado presente no cotidiano das escolas há muito, o tema só passou a ser objeto de estudo científico no início dos anos 70. O país pioneiro no estudo foi a Suécia, onde grande parte da sociedade demonstrou preocupação com a violência entre estudantes e suas consequências no âmbito escolar, tendo o tema, a partir daí, despertado o interesse dos demais países escandinavos.

No final de 1982, um episódio ocorrido na Noruega chamou a atenção das autoridades educacionais do país para o bullying, quando três crianças, com idade entre 10 e 14 anos, se suicidaram. As investigações do caso apontaram as situações de maus-tratos a que tais jovens foram submetidos por seus colegas de escola como principal motivação da tragédia. Em razão da grande mobilização nacional diante dos fatos, o Ministério da Educação da Noruega realizou, em 1983, uma campanha em larga escala, visando ao combate efetivo do bullying escolar.

Dan Olweus, pesquisador da Universidade de Berger, Noruega, iniciou, nessa época, um estudo que reuniu aproximadamente 84 mil estudantes, quase quatrocentos professores e cerca de mil pais de alunos. Todas as séries foram observadas, o que corresponderia, atualmente, no Brasil, a representantes desde o primeiro ano do ensino fundamental até o último ano do ensino médio. $\mathrm{O}$ objetivo principal de Olweus era avaliar as taxas de ocorrência e as formas pelas quais o bullying se apresentava na vida escolar das crianças e dos adolescentes de seu país.

O estudo constatou que um em cada sete alunos encontrava-se envolvido em casos de bullying, tanto no papel de vítima, como no de agressor. O levantamento realizado por Olweus deu origem a um programa 
de intervenção antibullying, que teve como objetivos desenvolver regras claras contra o bullying nas escolas, alcançar um envolvimento ativo por parte de professores e pais, aumentar a conscientização sobre o problema para desfazer mitos e ideias erradas sobre o bullying, bem como promover apoio e proteção às vítimas desse tipo de violência escolar.

A campanha nacional antibullying recebeu amplo apoio do governo norueguês, e acabou por reduzir em cerca de $50 \%$ a ocorrência do bullying nas escolas. $\mathrm{O}$ sucesso da iniciativa inspirou campanhas antibullying em países como a Inglaterra, o Canadá e Portugal.

Pesquisas sobre o fenômeno, ao redor do mundo, apontam para o crescimento do problema: estima-se que de $5 \%$ a $35 \%$ das crianças em idade escolar estejam envolvidas em condutas agressivas no ambiente educacional, seja como vítimas, ou como agressores ${ }^{1}$.

Nos Estados Unidos, o bullying é objeto de grande interesse, uma vez que lá tal prática está fortemente presente, tendo sido, inclusive, classificada como um conflito global pelas autoridades.

No Brasil, o atraso em identificar e enfrentar o problema foi significativo. Por aqui, o tema só começou a ser abordado junto à sociedade a partir do ano de 2000, quando Cleo Fante e José Augusto Pedra realizaram uma pesquisa bastante abrangente sobre o assunto.

Esse trabalho pioneiro resultou em um programa de combate ao bullying denominado "Educar para a Paz", colocado em prática na Escola Municipal Luiz Jacob, na cidade de São José do Rio Preto, São Paulo, no período de junho de 2002 a julho de $2004^{2}$. Graças a esses esforços, o tema bullying começou a ganhar espaço em debates públicos.

\footnotetext{
${ }^{1}$ SILVA, Ana Beatriz Barbosa. Bullying: mentes perigosas nas escolas. Rio de Janeiro: Objetiva, 2010. p. 111-112.

2 Disponível em $<$ http://www.bullying.pro.br/index.php?option=com_content\&view=article\&id=75>. Acesso em 08 maio 2011.
} 
A partir daí, diversas pesquisas sobre a incidência do bullying nas escolas brasileiras foram realizadas, as quais serão retratadas ao longo do presente trabalho.

A atenção da população para o tema, no Brasil, parece ter sofrido um aumento exponencial ao longo dos dois últimos anos, tendo em vista o elevado número de publicações de matérias nos principais jornais do país versando sobre o assunto, os debates com especialistas em programas de $\mathrm{TV}$, a crescente bibliografia que vem sendo editada sobre o tema ou, ainda, as ações judiciais de responsabilidade civil no bullying que vem "pipocando" nos últimos anos.

Não bastasse tudo isso, o episódio denominado "massacre de Realengo", ocorrido em abril deste ano de 2011, em uma escola na cidade do Rio de Janeiro, acabou por expor ainda mais o fenômeno bullying na mídia, tendo em vista que as investigações do caso apontaram como principal motivação da chacina a perseguição que o perpetrador teria sofrido quando era aluno da escola alvo do ataque.

Diante dessa nova e comprovada realidade, torna-se fundamental o estudo do fenômeno bullying, uma vez que só assim será possível combater efetivamente a violência entre crianças e adolescentes na fase de seu desenvolvimento, justamente quando estão formando seu caráter e personalidade para a vida adulta.

Atualmente, o bullying já é definido como um problema de saúde pública e, por isso mesmo, deve entrar na pauta de todos os profissionais que atuam na área médica, psicológica e assistencial de forma mais abrangente.

A falta de conhecimento sobre a existência, o funcionamento e as consequências do bullying propicia o aumento desordenado no número e na gravidade de novos casos, além de nos expor a situações trágicas, isoladas ou coletivas, que poderiam ter sido evitadas. 
Afinal, como ficar de braços cruzados diante de episódios escandalosos de violência entre os jovens no ambiente escolar, cada vez mais retratados nos meios de comunicação em todo o mundo? Como encarar com naturalidade uma prática que já motivou verdadeiros massacres nas escolas de todo o planeta, inclusive no Brasil, liderados justamente por aqueles que antes eram as vítimas do bullying praticado por seus colegas? Como calar-se diante de adultos que carregam, até hoje, o estigma de terem sido, um dia, alvos de bullying na infância e adolescência, o que destruiu, de forma irrecuperável, a sua auto-estima e auto confiança?

Por isso, é preciso mudar as lentes e despir-se de qualquer tipo de preconceito no estudo do bullying, pois, longe de representar uma prática natural, corriqueira e saudável entre as crianças, ele expõe não somente a intolerância às diferenças, como também dissemina os mais diversos preconceitos e revela a assimetria de poder nas relações interpessoais, dentro e fora dos muros escolares.

Ademais, é preciso compreender que pais e instituição de ensino são corresponsáveis na formação dos jovens e, portanto, impõe-se a atuação conjunta de ambos no combate ao bullying escolar.

Nesse sentido, é papel das escolas estarem atentas ao comportamento dos educandos, devendo agir ao primeiro sinal de agressividade demonstrado por seus alunos, de forma a cumprir o dever de vigilância que lhes é legalmente imposto. Assim, é função das instituições de ensino convocar os pais dos menores que se mostrarem envolvidos nas práticas de bullying escolar, a fim de que ambos traçem uma solução conjunta para o comportamento transgressor adotado pelos agressores.

Entretanto, uma vez comunicados pela escola do envolvimento de seus filhos com a prática de bullying, é dever dos pais procurar se inteirar da situação, através do diálogo com seus descendentes, para buscar a 
melhor maneira de enfrentar o problema, inclusive encaminhando-os para o tratamento que se mostrar adequado.

Dessa forma, nos casos em que, comprovadamente, a escola tenha tomado as medidas consideradas pedagogicamente essenciais para solucionar a situação, comunicando os pais dos menores sobre o envolvimento de seus filhos com o bullying, sem que os genitores tenham tomado qualquer atitude para reverter a situação, sustentamos que os responsáveis e a escola devem ser responsabilizados solidariamente pelos atos de bullying, quando estes venham a causar danos materiais e morais às vítimas.

A metodologia empregada ao longo do presente trabalho será dividir a problemática relacionada ao bullying escolar em dois grandes blocos. Em primeiro lugar, abordaremos as questões pertinentes ao bullying, enquanto fenômeno psicossocial.

Para tanto, no Capítulo I, serão apresentados o conceito do termo bullying, os mais notórios casos de violência motivados pelo bullying escolar, a legislação do estado do Rio de Janeiro que trata do tema, as principais pesquisas sobre a incidência do bullying nas escolas brasileiras e os critérios objetivos empregados para diferenciar o bullying das brincadeiras normais no contexto escolar.

Em seguida, tratar-se-á do tema sob o prisma da judicialização dos conflitos na sociedade atual, buscando inserir o fenômeno no contexto da sociedade contemporânea e serão apontadas as chaves para a prevenção e o combate do bullying escolar.

Por fim, a atenção será voltada para as questões jurídicas relacionadas ao bullying escolar, especialmente no que se refere à responsabilidade civil pelos atos de bullying praticados por menores no âmbito das escolas que venham a causar danos morais e materiais às vítimas. 
Nesse sentido, ao longo do Capítulo II, evidenciar-se-á que a prática de bullying é proibida pelo ordenamento jurídico brasileiro. Em sequência, a responsabilidade pelos atos de bullying escolar praticados por menores será situada no âmbito da responsabilidade civil por fato de terceiro e, mais especificamente, na esfera da responsabilidade civil dos pais pelos atos dos filhos menores e da responsabilidade dos estabelecimentos de ensino pelos atos dos educandos, salientando-se os pressupostos para a incidência de ambas. Por fim, analisar-se-á como a jurisprudência vem se posicionando sobre o tema.

O que se propõe, ao longo desse trabalho, é elucidar as principais questões relativas ao fenômeno bullying, trazendo um referencial teórico para os interessados no tema, imprescindível para o diagnóstico e combate desse tipo de violência no âmbito escolar.

Afinal, o conhecimento do problema é apenas o início da longa jornada que ainda se terá de percorrer até que o bullying escolar seja erradicado da realidade educacional do Brasil e do mundo. 


\section{BULLYING ESCOLAR: IDENTIFICAÇÃO, INCIDÊNCIA NAS INSTITUIÇÕES BRASILEIRAS E ESTRATÉGIAS DE COMBATE}

Neste capítulo serão apresentados o conceito de bullying, os critérios de distinção do bullying das brincadeiras usuais no contexto escolar, os levantamentos realizados sobre a incidência do bullying nas escolas brasileiras, o tratamento legal do bullying escolar no estado do Rio de Janeiro e os diferentes meios de prevenção e combate ao bullying escolar. Além disso, buscar-se-á analisar o estudo do tema sob o prisma da judicialização dos conflitos na sociedade atual, inserindo o fenômeno no contexto da sociedade contemporânea, de forma a esclarecer quais valores a prática de bullying escolar, em regra voltada contra pessoas tidas como diferentes, revela.

\subsection{O Conceito de Bullying}

Bullying é um termo em inglês, ainda sem tradução no Brasil, utilizado para descrever atos de violência física ou psicológica, intencionais e repetidos, praticados por um indivíduo (bully) ou grupo de indivíduos, com o objetivo de intimidar ou agredir outro indivíduo (ou grupo de indivíduos) incapaz(es) de se defender ${ }^{3}$.

O bullying pode, ainda, ser conhecido com outros nomes em diferentes países, tais como: assédio moral, mobbing (Noruega e Dinamarca), mobbning (Suécia e Finlândia), harassment (Eua), acoso (Espanha), entre outras denominações ${ }^{4}$.

\footnotetext{
${ }^{3}$ Disponível em: <http://pt.wikipedia.org/wiki/bullying >. Acesso em 11 abril 2011.

${ }^{4}$ CALHAU, Lélio Braga. Bullying: o que você precisa saber: identificação, prevenção e repressão. $2^{\mathrm{a} e d . ~ N i t e r o ́ i: ~ I m p e t u s, ~ 2010 . ~ p . ~} 6$.
} 
No que se refere ao bullying escolar, objeto do presente estudo, o termo compreende todas as formas de atitudes agressivas, intencionais e repetidas, que ocorrem sem motivação evidente, adotadas por um ou mais estudantes contra outro(s), causando dor e angústia, e executadas dentro de uma relação desigual de poder. Portanto, os atos repetidos entre iguais (estudantes), a falta de motivação dos ataques e o desequilíbrio de poder são as características essenciais, as quais tornam possível a intimidação da vítima $^{5}$.

Vale ressaltar que, segundo Dan Olweus, pesquisador norueguês apontado como pioneiro no estudo do bullying escolar, não resta configurado o bullying quando dois estudantes com aproximadamente a mesma força (física ou psicológica) estão a lutar ou envolvidos numa disputa. Assim, quando se utiliza o termo bullying, este inclui um desequilíbrio de poder entre o agressor e a vítima, ou seja, o aluno que está exposto a ações negativas tem dificuldade de se defender ou está indefeso contra o aluno ou alunos que o provocam. Essa relação de poder assimétrico verifica-se porque a vítima não tem competências suficientes ou capacidade para integrar o seu grupo de pares quando existe um domínio social através de meios manifestamente agressivos ${ }^{6}$.

Ainda conforme Olweus, para restar caracterizado o bullying escolar, a vítima tem que ser alvo dos ataques, no mínimo, duas vezes durante o ano letivo, a fim de preencher-se o critério da repetitividade das agressões.

Por não existir uma palavra na língua portuguesa capaz de expressar todas as situações de bullying possíveis, a seguir relacionamos algumas ações que podem estar presentes, separadas conforme a classificação sugerida pelos estudiosos do tema ${ }^{7}$ :

\footnotetext{
${ }^{5}$ Disponível em <http://www.observatoriodainfancia.com.br/IMG/pdf/doc-154.pdf>. Acesso em 11 abril 2011

${ }^{6}$ CARVAlHOSA, Susana. Prevenção da Violência e do Bullying em Contexto Escolar. Lisboa: Climepsi Editores, 2010. p. 8.

${ }^{7}$ SILVA, Ana Beatriz Barbosa. Op. cit. p. 23-24.
} 
- VERBAL: insultar, ofender, xingar, fazer gozações, colocar apelidos pejorativos, fazer piadas ofensivas, "zoar".

- FÍSICO E MATERIAL: bater, chutar, espancar, empurrar, ferir, beliscar, roubar/ furtar/destruir os pertences da vítima, atirar objetos contra as vítimas.

- PSICOLÓGICO E MORAL: Irritar, humilhar e ridicularizar, excluir, isolar, ignorar, desprezar ou fazer pouco caso, discriminar, aterrorizar e ameaçar, chantagear e intimidar, tiranizar, dominar, perseguir, difamar, passar bilhetes e desenhos entre os colegas de caráter ofensivo, fazer intrigas, fofocas ou mexericos (mais comum entre as meninas).

- VIRTUAL OU CYBERBULLYING: Na era da informática, novas formas de bullying surgiram através da utilização de aparelhos e equipamentos de comunicação (celular e internet), os quais são capazes de difundir, em progressão geométrica, as ofensas dirigidas às vítimas. Essa forma de bullying é conhecida como cyberbullying. Os ataques ocorrem por meio de ferramentas tecnológicas como celulares, internet e seus recursos (e-mails, sites de relacionamentos, tais como: MSN, Orkut, YouTube, Skype, Twitter, MySpace, Facebook, blogs, fotoblogs, vídeos).

Valendo-se do anonimato, os bullies virtuais inventam mentiras, espalham rumores, boatos depreciativos e insultos sobre outros estudantes. Além de a propagação das difamações ser praticamente instantânea, o efeito multiplicador do sofrimento das vítimas é imensurável. O cyberbullying extrapola, em muito, os muros das escolas e expõe a vítima ao escárnio público. Os agressores, normalmente, criam um perfil falso (em sites de relacionamento ou e-mails), fazendo-se passar por outra pessoa, muitas vezes postando fotografias alteradas das vítimas em montagens constrangedoras, as quais são divulgadas em sites diversos. Além disso, alguns agressores invadem o e-mail pessoal das vítimas, que passam a 
enviar mensagens difamatórias e caluniosas a outras pessoas, como se a própria vítima fosse a responsável por isso.

- SEXUAL: abusar, violentar, assediar, insinuar.

\section{2. Bullying versus brincadeiras normais no ambiente escolar}

Diante desse cenário, questão que se coloca é: como distinguir brincadeiras normais e saudáveis entre os estudantes da prática de bullying nas escolas? Os estudos sobre o bullying fizeram a distinção entre as brincadeiras naturais, típicas da vida estudantil, daquelas que ganham requinte de crueldade e extrapolam todos os limites de respeito pelo outro.

Segundo Lélio Braga Calhau, Promotor de Justiça do Ministério Público do Estado de Minas Gerais e estudioso do tema, deve prevalecer o bom senso na avaliação voltada a diferenciar o bullying de simples brincadeiras. Segundo ele, um dos erros que deve ser evitado numa avaliação de situação ou não de bullying é a precipitação.

Os céticos da existência do bullying criticam o suposto "modismo" da mídia, professores, psicólogos etc., em apontar o bullying em todas as situações de conflito entre indivíduos. De fato, o autor admite que existem excessos, principalmente em razão do interesse afoito da mídia em divulgar os casos com maior repercussão. Portanto, Lélio recomenda redobrar o cuidado para uma análise o mais cautelosa e isenta possível.

Ainda, esclarece o autor que existem alguns critérios básicos estabelecidos pelo pesquisador Dan Olweus para identificar as condutas de bullying e diferenciá-las de outras formas de violência e das brincadeiras próprias da idade. Os critérios estabelecidos são: ações repetitivas contra a mesma vítima num período prolongado de tempo; desequilíbrio de poder, o que dificulta a defesa da vítima; ausência de motivos que justifiquem os 
ataques; sentimentos negativos mobilizados e as sequelas emocionais vivenciadas pelas vítimas de bullying ${ }^{8}$.

Afinal, é notório que, desde os tempos mais remotos, as brincadeiras acontecem de forma natural e espontânea entre os alunos. Eles brincam, "zoam", colocam apelidos uns nos outros e tiram "sarros" dos demais. No entanto, quando as "brincadeiras" são realizadas repletas de "segundas intenções" e de perversidade, elas se tornam verdadeiros atos de violência que ultrapassam os limites suportáveis de qualquer um.

Nesse sentido, é necessário entendermos que brincadeiras normais e sadias são aquelas nas quais todos os participantes se divertem. Quando apenas alguns se divertem à custa de outros que sofrem e são humilhados, isso ganha outra conotação, bem diversa de um simples divertimento, caracterizando-se o bullying escolar, que, conforme já explicitado anteriormente, abrange todos os atos de violência (física ou não) que ocorrem de forma intencional e repetitiva contra um ou mais alunos, impossibilitados de fazer frente às agressões sofridas.

Portanto, aquilo que antes era algo sem definição específica hoje tem nome, sobrenome, descrição e reconhecimento psicossocial ${ }^{9}$.

De fato, nos dias atuais, o bullying tornou-se um problema endêmico nas escolas de todo o mundo, ocorrendo desde a pré-escola até o ensino universitário, fazendo com que o cotidiano de muitas crianças, jovens e adultos seja insuportável.

Pode-se afirmar que o bullying está presente, de forma democrática, em $100 \%$ das escolas em todo o mundo, públicas ou particulares. O que pode variar são os índices encontrados em cada realidade escolar. Isso

\footnotetext{
${ }^{8}$ CALHAU, Lélio Braga. Op. cit. p.7.

9 SILVA, Ana Beatriz Barbosa. Op. cit. p.13-14.
} 
decorre do conhecimento da situação e da postura que cada instituição de ensino adota ao se deparar com casos de violência entre os alunos ${ }^{10}$.

\subsection{Casos de violência motivados pelo bullying escolar}

Casos de violência motivados pelo bullying são cada vez mais frequentes nos noticiários de todo o mundo. Abaixo, listamos alguns dos episódios que tiveram maior repercussão na mídia.

Um dos casos mais emblemáticos e com fim trágico ocorreu nos Estados Unidos, no ano de 1999, no colégio Columbine High School, em Denver, Colorado.

Os estudantes Eric Harris, de 18 anos, e Dylan Klebold, de 17, assassinaram 12 estudantes e um professor. Deixaram mais de vinte pessoas feridas e se suicidaram em seguida. A motivação para o ataque seria a vingança pela exclusão escolar que os dois teriam sofrido durante muito tempo.

O massacre suscitou muitas discussões sobre maus-tratos aos adolescentes nas escolas e segurança nas instituições de ensino norteamericanas, tornando a região referência em relação à violência escolar. Em 2002, esse episódio deu origem ao premiado documentário Tiros em Columbine, dirigido por Michael Moore, que questiona o culto à violência e o fácil acesso às armas nos Estados Unidos.

Outro caso igualmente chocante ocorreu em abril de 2007, na Virginia Tech University, também nos Estados Unidos. O sul-coreano Cho Seung-Hui, de 23 anos, entrou fortemente armado na universidade, abriu fogo em dois pavilhões do campus, matando mais de trinta pessoas e, em seguida, suicidou-se com um tiro na cabeça. Os noticiários da época revelaram que o jovem era calado, introvertido, fechado, tinha poucos

\footnotetext{
${ }^{10}$ Ibid. p.117.
} 
amigos e já havia passado por tratamentos psiquiátricos por tentativa de suicídio.

Algumas pessoas que presenciaram o ocorrido relataram que o autor da chacina era alvo de preconceito, humilhações e intimidações por parte dos colegas, por não corresponder ao perfil dos alunos americanos que frequentavam aquela escola.

Antes do episódio, o sul-coreano enviou, pelo correio, um pacote para a sede da emissora de televisão NBC, em Nova York, que continha uma carta, fotos e vídeos em que o jovem aparecia armado e com vestimentas de guerra. Em um dos trechos do vídeo, o jovem diz "vocês tiveram uma centena de bilhões de formas de evitar esse momento. Mas vocês dicidiram derramar meu sangue. Me encurralaram e me deram apenas uma opção. A decisão foi sua. Agora vocês têm sangue nas mãos, e nunca vão conseguir lavá-lo. Vocês destruíram o meu coração, violentaram a minha alma, queimaram a minha consciência. Vocês pensaram que era a vida de um menino patético que extinguiam. Graças a vocês, eu morro como Jesus Cristo, para inspirar gerações de pessoas fracas e indefesas".

Em outros trechos, o jovem questiona: "Vocês sabem o que se sente quando cospem no seu rosto e lixo é empurrado garganta abaixo? Vocês sabem qual é a sensação de cavar a própria sepultura?(...) Vocês sabem o que é ser humilhado e empalado numa cruz? E ser deixado sangrando para a sua diversão? Vocês nunca sentiram uma pitada de dor em suas vidas inteiras."

O sul-coreano conclui: "Vocês tiveram tudo o que desejavam. Suas mercedes não eram o bastante, seus pirralhos. Seus colares de ouro não eram o bastante, seus esnobes. Seus fundos de herdeiro não eram o bastante. Sua vodca e seu conhaque não eram o bastante. Todas as suas devassidões 
não foram o bastante. Não eram suficientes para preencher suas necessidades hedonistas. Vocês tiveram tudo."11

O sul-coreano comparou-se a um mártir (Jesus Cristo) e culpou a intolerância e a perseguição sofrida no ambiente universitário como motivadores do massacre. Através de sua atitude, Cho buscou morrer como um herói, encorajando os demais alunos vítimas de bullying a fazerem o mesmo, tornando-se uma referência para eles. Só assim conseguiu sair do anonimato e da indiferença para ser realmente notado, em toda a sua complexidade.

No Brasil, também já ocorreram episódios semelhantes aos acima relatados. Em janeiro de 2003, a cidade de Taiuva, no interior de São Paulo, foi palco de grande tragédia. O jovem Edimar de Freitas, de 18 anos, entrou armado na escola em que havia concluído o ensino médio e abriu fogo contra cinquenta pessoas que estavam no pátio, ferindo oito, e se matou em seguida. Segundo as investigações, a barbárie foi motivada pelos constantes apelidos e humilhações que Edimar recebia, por ser obeso. Ex-colegas do rapaz disseram que ele prometia vingança, afirmando que todos iriam se arrepender.

Na cidade de Remanso, norte da Bahia, no ano de 2004, um rapaz de 17 anos, após sofrer muitas humilhações e receber baldes de lama sobre sua cabeça, matou duas pessoas e feriu mais três. O jovem também tentou suicídio, mas foi impedido e desarmado.

Outro caso ocorreu na cidade de Silva Jardim (RJ). Samuel Teles da Conceição, de 17 anos, era alvo de constantes ofensas e brincadeiras maldosas. Em setembro de 2008, ele foi espancado com socos na cabeça, dentro da sala de aula e no pátio da escola, por vários colegas de classe. $\mathrm{O}$

\footnotetext{
${ }^{11}$ Disponível em <http://www.bbc.co.uk/portuguese/reporterbbc/story/2007/04/070419_matadormensagemg.shtml> Acesso em 06 abril 2011.
} 
motivo desse ataque teria sido o novo corte de cabelo de Samuel. Dias depois, o adolescente veio a falecer, vítima de meningoencefalite purulenta e contusão cerebral ${ }^{12}$.

Recentemente, no último dia 07/04/11, o Rio de Janeiro testemunhou um massacre de proporções nunca antes vistas no Brasil, tendo o mesmo sido denominado como o "columbine brasileiro" por alguns internautas, assim que a notícia foi divulgada na internet.

Wellington Menezes de Oliveira comandou a chacina de doze crianças na escola municipal Tasso da Silveira, em Realengo, zona oeste do Rio. Ao que tudo indica, a matança foi motivada pelo bullying sofrido pelo autor quando ele era aluno do colégio, pois, segundo depoimento de excolegas do atirador, este recebia apelidos discriminatórios e era alvo de intimidações constantes na sala de aula. ${ }^{13}$ De fato, o bullying é assunto central na série das sete gravações do atirador divulgadas pela polícia após a recuperação do seu HD.

Em um dos vídeos divulgados, Wellington diz que "A maioria das pessoas que me desrespeitam, acham que eu sou um idiota, se aproveitam da minha bondade, me julgam antecipadamente. São falsas, desleais. Descobrirão quem eu sou da maneira mais radical. Uma ação que farei por meus semelhantes que são humilhados, agredidos, desrespeitados em vários locais, principalmente em escolas e colégios, pelo fato de serem diferentes, de não fazerem parte grupo dos infiéis, dos desleais, dos falsos, dos corruptos, dos maus. São humilhados por serem bons". (grifos nossos)

Portanto, percebe-se que, para Wellington, "fiéis ou irmãos" são os que sofrem bullying. Já "infiéis e fornicadores" são os que praticam o bullying ou compactuam com a prática.

\footnotetext{
${ }^{12}$ SILVA, Ana Beatriz Barbosa. Op. cit. p. 118-119.

${ }^{13}$ O Globo. Wellington Menezes era vítima de 'bullying' nos tempos da escola. Rio de Janeiro, 08 abril 2011. Disponível em <http://oglobo.globo.com/rio/mat/2011/04/07/wellington-menezes-eravitima-de-bullying-nos-tempos-da-escola-924190244.asp>. Acesso em 10 abril 2011.
} 
Já em outro vídeo, Wellington diz que sua ação servirá como exemplo para que outros não sofram o mesmo tratamento que ele diz ter sofrido. Em suas palavras, “(...) que o ocorrido sirva de lição, principalmente às autoridades escolares, para que descruzem os braços diante de situações em que alunos são agredidos, humilhados (...)". (grifos nossos)

Wellington afirma "as vezes que mais doía era (sic) quando eles praticavam essas covardias contra mim e todos em volta riam, debochavam, se divertiam, sem se importar com meus sentimentos". (grifos nossos)

Ainda, afirma o atirador em uma das gravações "eu fui fraco, eu fui medroso. Mas me tornei um combatente, uma pessoa forte, corajosa, que tem como objetivo a defesa dos irmãos fracos, que ainda se encontram nas condições, sendo incapazes de se defender. Morri para inspirar vocês, irmãos, a se defenderem e se fortalecerem. Meu desejo é que se estabeleça uma união entre vocês, que os irmãos mais fortes e corajosos fiquem atentos para proteger os irmãos mais fracos." 14

Além dos vídeos, a polícia também encontrou fotos que lembram as deixadas por outros atiradores, como o assassino do massacre de Virginia Tech, Cho Seung-hui. Na imagem, Wellington segura as armas e simula disparos. Cho é citado em um dos vídeos como "ícone na luta contra os infiéis", ao lado de Edimar Aparecido Freitas, que atirou contra alunos de uma escola em Taiuva, e de Casey Heynes, australiano que ficou famoso por um vídeo em que reage ao bullying ${ }^{15}$.

\footnotetext{
${ }^{14}$ Vídeos disponíveis em < http://www.youtube.com/watch?v=mTPV6cy_tPE $>$. Acesso em 15 abril 2011.

${ }^{15}$ Folha de São Paulo. Descobrirão quem eu sou da maneira mais radical. São Paulo, 13 abril 2011. Disponível em <http://www1.folha.uol.com.br/cotidiano/902211-descobrirao-quem-eu-souda-maneira-mais-radical-diz-atirador.shtml>. Acesso em 16 abril 2011.
} 
Gustavo Teixeira, psiquiatra entrevistado pelo Jornal Folha de São Paulo e autor do livro "Manual antibullying", afirma que, isoladamente, a prática não pode ser considerada responsável pela tragédia:

"O bullying pode ter sido um dos gatilhos, mas para uma pessoa que já tinha uma doença psiquiátrica. $\mathrm{O}$ que pode ter ocorrido é que a prática acabou fazendo com que aquela loucura fosse ambientada na escola, como ocorreu" ${ }^{16}$.

Nesse sentido, conforme o psiquiatra, a partir dos assédios morais sofridos, uma doença mental que ainda estava latente foi deflagrada, provocando distorções dramáticas da realidade.

Ao se referir aos seus "semelhantes", Wellington aponta que o motivo da exclusão e da humilhação das vítimas do bullying é o fato de eles serem diferentes, e de não fazerem parte do grupo dos agressores. Ou seja, evidencia-se que as vítimas do bullying são aquelas tidas como distintas, em função de se destacarem dos demais por alguma característica específica, o que as faz serem rechaçadas pelo grupo e hostilizadas por seus colegas constantemente.

Ora, aquilo que antes parecia algo distante da realidade brasileira, somente visto em noticiários estrangeiros e filmes, agora faz parte também do repertório nacional, acrescentando um triste capítulo à história da violência escolar no Brasil.

Esse acontecimento, de forma trágica e inesperada, contribuiu para aquecer, ainda mais, o debate sobre o bullying escolar na sociedade brasileira e sobre as consequências nefastas que ele pode trazer, em função da mágoa e do ódio que tal prática deixa naqueles que um dia foram vítimas.

\footnotetext{
${ }^{16}$ Folha de São Paulo. Só bullying não é capaz de explicar massacre no Rio. São Paulo, 10 abril 2011. Disponível em <http://www1.folha.uol.com.br/cotidiano/900696-so-bullying-nao-e-capazde-explicar-massacre-no-rio.shtml>. Acesso em 11 abril 2011.
} 
Além disso, massacres como os acima descritos revelam que os perpetradores, depois de muito sofrerem, utilizaram a arma como instrumento de "superação" do poder que os subjugava. Ainda, seus alvos, em praticamente todos os casos, não eram os alunos que os agrediam ou intimidavam. Quando resolveram reagir, o fizeram contra todos da escola, pois todos teriam se omitido e ignorado seus sentimentos e o seu sofrimento, adotando a postura de espectadores passivos e coniventes.

Ademais, o fato de Wellington se referir a outros jovens que também protagonizaram massacres como exemplos e inspiradores da sua ação demonstra que tais episódios criam uma espécie de efeito cascata, já que os primeiros inspiram os próximos, e assim por diante.

Diante desse cenário, a pergunta que fica é: quantos casos como estes precisarão se repetir para que o fenômeno bullying passe a ser encarado com a devida seriedade?

Em entrevista concedida ao Jornal O Globo ${ }^{17}$, após a repercussão do massacre na escola Tasso da Silveira, o psiquiatra Frank Ochberg, consultor do FBI que orientou a direção da Columbine High School, em Colorado, no processo de recuperação após a chacina, salienta que o mais importante nos dias seguintes a uma tragédia como essa é que os pais e professores consigam restabelecer uma sensação de normalidade para as crianças e adolescentes que testemunharam a tragédia.

Ele conta que a mudança fundamental nas escolas americanas após Columbine foi a criação de grupos multidisciplinares para a avaliação de ameaças. Ochberg, que também participou da investigação da chacina de Virginia Tech, em 2007, diz que a ação desses grupos intercepta problemas antes que eles cresçam e virem um perigo.

\footnotetext{
${ }^{17}$ OCHBERG, Frank. A escola ainda é um lugar seguro. O Globo, Rio de Janeiro, p.13, 10 abril 2011.
} 
Dessa forma, a maioria das escolas americanas tem hoje um grupo de avaliação de ameaças. Todas as universidades e escolas de ensino médio tiveram que aprender a ter uma comunicação regular sobre casos de estudantes com alguma perturbação, através de reuniões que envolvem um professor, um agente de segurança e um terapeuta, a fim de haver um intercâmbio de pontos de vista diferentes sobre algum aluno que esteja tendo um comportamento diferente, como, por exemplo, sofrendo ou praticando bullying.

Assim, por meio do acompanhamento, torna-se possível encontrar os casos de estudantes que se tornam perigosos, rompendo-se, dessa maneira, o código de silêncio que faz com que os alunos nunca relatem problemas ou situações de perigo a um adulto. Segundo o psiquiatra, esta foi uma das grandes mudanças dos Eua após Columbine.

O exemplo dos Estados Unidos deve ser observado pelas escolas brasileiras, já que, em se tratando de violência escolar, eles são muito mais experientes que o Brasil e, portanto, já desenvolveram maneiras de lidar com o problema, as quais podem se mostrar muito úteis na prevenção do bullying escolar nas instituições de nosso país.

\section{4. Legislação e o bullying}

No Rio de Janeiro, a legislação vigente impõe que os casos de bullying e de violência contra crianças e adolescentes em escolas públicas e particulares sejam notificados à polícia. A lei instituindo a medida foi sancionada pelo governador Sérgio Cabral no dia 23 de setembro de 2010 e prevê multa de três a 20 salários mínimos (até $R$ \$ 10.200) para instituições de ensino que descumprirem a norma. Tal medida já era obrigatória em hospitais e estabelecimentos de saúde. 
Pelas regras instituídas pela lei de 2010, professores e funcionários de escolas devem denunciar os casos a delegacias e conselhos tutelares. A obrigatoriedade da notificação permite que os casos sejam investigados. Segundo o autor, deputado estadual André Corrêa (PPS), os estabelecimentos educacionais, onde a criança e o adolescente frequentam diariamente, dotados de equipes multiprofissionais, estão capacitados para detectar estes casos.

Apesar de a lei estar em vigor há mais de seis meses, o deputado admitiu, em entrevista concedida ao Jornal $O$ Globo, que a regra não “vingou”. Até agora, segundo o parlamentar, nenhuma escola foi multada.

Um levantamento feito pelo Jornal O Globo, publicado em 17 de abril de $2011^{18}$, revela que, na prática, as escolas não notificam os casos de bullying em conselhos tutelares ou na polícia.

Segundo entrevista concedida ao referido Jornal, a mãe de um menino hoje com 11 anos conta que passou, entre 2009 e 2010, por um dos períodos mais difíceis de sua vida. Poucos meses após ter matriculado o filho numa nova escola, percebeu as primeiras marcas de agressão na criança. A situação foi se agravando e, apesar dos apelos, ela diz ter sofrido com o descaso do colégio, tendo, ao final, que trocar o filho de colégio. De acordo com a mãe:

"Meu filho chegou ao ponto de ter uma crise renal em consequência do que sofria na escola. Descobrimos que outros alunos não o deixavam ir ao banheiro, alegando que assim ele estaria cumprindo uma prova para poder pertencer a um grupo. Levando em conta que o bullying resulta em lesões corporais, ofensas morais e danos psicológicos, a escola não poderia ter ficado inerte aos fatos"

\footnotetext{
${ }^{18}$ O Globo. Apesar de lei determinar, escolas não notificam casos de bullying em conselhos tutelares ou na polícia. Rio de Janeiro, 16 abril 2011. Disponível em

<http://oglobo.globo.com/rio/mat/2011/04/16/apesar-de-lei-determinar-escolas-nao-notificamcasos-de-bullying-em-conselhos-tutelares-ou-na-policia-924258087.asp>. Acesso em 17 abril 2011.
} 
Sem encontrar eco na instituição de ensino, um dos caminhos adotados pela mãe foi procurar o Conselho Tutelar da região. A partir da lei do ano de 2010, a iniciativa obrigatoriamente deveria ser das próprias escolas, sob pena de multa, mas não é o que tem ocorrido.

O Jornal O Globo entrou em contato com os dez conselhos da capital do Rio de Janeiro. Em oito, a informação foi a mesma: com raríssimas exceções, os relatos de bullying sempre chegam somente através dos pais. Um conselho não quis passar informações sobre as notificações e, no outro, ninguém atendeu às ligações do Jornal.

O delegado Fábio Corsino, titular da Delegacia da Criança e do Adolescente Vítima (Dcav), também afirma que não tem sido informado pelos colégios. Segundo ele:

"Seria importante que essas notificações chegassem; a escola tem a obrigação de agir. O bullying, em si, não é tipificado como um crime, mas pode haver uma série de delitos envolvidos nessa prática, como lesão corporal ou constrangimento ilegal. $\mathrm{O}$ ideal é que possamos fazer uma avaliação caso a caso".

Segundo a psiquiatra e estudiosa do tema Ana Beatriz Barbosa Silva, muitas escolas particulares abafam os casos de bullying em suas dependências, por receio de perderem "clientes".

Entretanto, ela chama atenção para o fato de que, além de apresentar qualidade de ensino, a boa escola não é aquela onde o bullying necessariamente não ocorra, mas sim aquela que, quando ele existir, saiba enfrentá-lo com coragem e determinação. Assim, para ela, a omissão na notificação dos casos de bullying para as Varas da Infância e da Adolescência é danosa para todos, pois dificulta e até impossibilita as ações preventivas que poderiam coibir a proliferação do problema ${ }^{19}$.

${ }^{19}$ SILVA, Ana Beatriz Barbosa. Op. cit. p.118. 
Além disso, o prefeito de Belo Horizonte deve sancionar, no decorrer do ano de 2011, uma lei, aprovada pela Câmara Municipal, que prevê a montagem de equipes multidisciplinares nas escolas, a fim de identificar praticantes e vítimas de agressões físicas e psicológicas no ambiente escolar, bem como o desenvolvimento de campanhas educativas.

$\mathrm{O}$ projeto, de autoria do vereador Adriano Ventura (PT), determina ainda a capacitação de docentes e de equipes pedagógicas para realizar palestras, debates e reflexões a respeito da violência escolar ${ }^{20}$.

Por fim, um anteprojeto de lei proposto pelo Ministério Público de São Paulo tipifica o bullying como crime, com pena de um a quatro anos de reclusão, além de multa. Prevê, ainda, que caso o bullying seja cometido por mais de uma pessoa, por meio eletrônico ou outro tipo de mídia (caso do cyberbullying), a pena será aumentada de um terço até a metade. Para uma lesão grave, será prevista reclusão de cinco a dez anos. Em caso de morte, reclusão de 12 a 30 anos, além da multa prevista para homicídios.

Como o bullying e o cyberbullying são praticados, na imensa maioria dos casos, por crianças e adolescentes, os promotores vão precisar adaptar a tipificação penal dessas práticas ao que prevê o Estatuto da Criança e do Adolescente.

O anteprojeto será submetido no próximo dia 3 de junho de 2011 à aprovação na Promotoria e, depois, será encaminhado ao Procurador-Geral do Ministério Público de São Paulo, Fernando Grella, que deverá enviar o texto a um deputado para que o documento seja encaminhado ao Congresso $^{21}$.

\footnotetext{
${ }^{20}$ O Globo. Belo Horizonte faz lei para combater bullying. Rio de Janeiro, 13 maio 2011. Disponível em <http://oglobo.globo.com/educacao/mat/2011/05/13/belo-horizonte-faz-lei-paracombater-bullying-924451021.asp >. Acesso em 14 maio 2011.

${ }^{21}$ Disponível em <http://www.conjur.com.br/2011-mai-29/falta-lei-justica-quem-decidebullying>. Acesso em 30 maio 2011.
} 


\section{5. Pesquisas sobre o bullying no Brasil}

No Brasil, as pesquisas e a atenção voltadas ao tema do bullying ainda se dão de forma incipiente. A Associação Brasileira Multiprofissional de Proteção à Infância e à Adolescência, ABRAPIA, se dedica a estudar, pesquisar e divulgar o fenômeno bullying desde 2001.

No período compreendido entre novembro e dezembro de 2002 e março de 2003, a ABRAPIA realizou uma pesquisa, por meio de questionários distribuídos a 5.875 alunos de $5^{\text {a }}$ a $8^{\mathrm{a}}$ série de 11 escolas (nove públicas e duas particulares), no município do Rio de Janeiro, revelando os seguintes resultados ${ }^{22}$ :

- 40,5\% desses alunos admitiram ter estado diretamente envolvidos em atos de bullying naquele ano, sendo 16,9\% alvos, 10,9\% alvos/autores e $12,7 \%$ autores de bullying.

- Os meninos estão envolvidos com o bullying com uma frequência maior (50,5\%), tanto como autores, quanto como alvos. Já entre as meninas, embora com menor frequiência (49,5\%), o bullying também ocorre e se caracteriza, principalmente, como prática de exclusão ou difamação (o chamado bullying indireto)

- As agressões ocorrem principalmente na própria sala de aula $(60,2 \%)$, durante o recreio $(16,1 \%)$ e no portão das escolas $(15,9 \%)$.

- Em torno de 50\% das vítimas admitem que não relataram o fato aos professores, tampouco aos pais.

22 Disponível em <http://www.observatoriodainfancia.com.br/article.php3?id_article=232>. Acesso em 12 abril 2011. 
Os dados revelados pela pesquisa demonstram que, embora o bullying não houvesse sido objeto de atenção até bem recentemente no Brasil, aproximadamente $50 \%$ dos estudantes do país estavam envolvidos com essa prática na época da realização do levantamento pela ABRAPIA.

No ano de 2009, a ONG PLAN, organização não governamental voltada à defesa dos direitos da infância, realizou a pesquisa "Bullying no Ambiente Escolar", selecionando cinco escolas de cada uma das cinco regiões geográficas do Brasil, sendo vinte públicas municipais e cinco particulares, com o fim de instruir a sua campanha "Aprender sem medo".

Participaram do estudo 5.168 alunos que responderam ao questionário. A pesquisa aponta que a ocorrência do bullying emerge em um clima generalizado de violência no ambiente escolar, considerando-se que $70 \%$ da amostra de estudantes responderam ter presenciado cenas de agressões entre colegas, enquanto $30 \%$ deles declararam ter vivenciado ao menos uma situação violenta no mesmo período. Ademais, quase 9\% dos alunos afirmaram ter visto colegas serem maltratados várias vezes por semana e outros $10 \%$ afirmaram ver essas cenas todos os dias.

A referida pesquisa mostra que o bullying é mais comum nas regiões Sudeste e Centro-Oeste do País e que a incidência maior está entre os adolescentes na faixa de 11 a 15 anos de idade.

Quanto aos motivos que os levam a sofrer ou a praticar agressões, os participantes tiveram dificuldades para indicá-los. No entanto, tendem a considerar que os agressores buscam obter popularidade junto aos colegas, que necessitam ser aceitos pelo grupo de referência e que se sentiram poderosos em relação aos demais, tendo esse status reconhecido na medida em que seus atos são observados e, de certa forma, consentidos pela omissão e falta de reação dos atores envolvidos.

Já as vítimas foram descritas pelos respondentes como pessoas que apresentam alguma diferença em relação aos demais colegas, como um 
traço físico marcante, algum tipo de necessidade especial, o uso de vestimentas consideradas diferentes ou a posse de objetos e/ou o consumo de bens indicativos de status socioeconômico superior ao dos demais alunos. Elas foram apontadas pelo conjunto de respondentes como pessoas tímidas, inseguras e passivas, o que faz com que os agressores as considerem merecedoras das agressões, dado seu comportamento frágil e inibido.

A pesquisa mostra, ainda, que é maior o número de vítimas do sexo masculino: mais de 34,5\% dos meninos pesquisados foram vítimas de maus tratos ao menos uma vez no ano letivo de 2009, sendo 12,5\% vítimas de bullying, caracterizado, para a pesquisa em referência, por agressões com frequência superior a três vezes no ano letivo.

Apesar das altas taxas de práticas violentas, os alunos do sexo masculino pesquisados tenderam a minimizar a gravidade dessas ocorrências, alegando que foram brincadeiras de mau gosto, ou que não deram importância ao fato porque os colegas não mereceriam essa consideração.

Já as meninas que sofreram maus tratos ao menos uma vez durante o ano de 2009 (23,9\% da amostra de meninas pesquisada) ou tornaram-se vítimas de bullying (7,6\% dessa mesma amostra) apresentaram outro padrão de resposta às agressões sofridas, manifestando sentimentos de tristeza, mágoa e aborrecimento.

Quanto ao bullying no ambiente virtual - cyberbullying- os dados revelam que $16,8 \%$ dos respondentes são vítimas; $17,7 \%$ são praticantes e apenas 3,5\% são vítimas e praticantes ao mesmo tempo. Independente da idade das vítimas, o envio de e-mails maldosos foi o tipo de agressão mais frequente, sendo praticado com maior frequência pelos alunos do sexo masculino. Entre as meninas pesquisadas, o uso de ferramentas e de sites de relacionamento foram as formas mais utilizadas. 
Segundo a pesquisa, tanto no ambiente virtual, como no ambiente escolar, as vítimas tendem a não reagir aos atos sofridos e apresentam sentimentos de desconforto, apatia, irritabilidade e tristeza. Ademais, as vítimas foram descritas pelos agressores como pessoas fracas e que mereceram o "castigo", sem que a maior parte deles manifestasse qualquer sentimento de remorso ou compaixão.

Quanto às consequências da prática de bullying, os próprios respondentes ressaltaram os prejuízos sobre o processo de aprendizagem, uma vez que tanto as vítimas, quanto os agressores, perderam o interesse pelo ensino e não se sentiram motivados a frequentar as aulas ${ }^{23}$.

Outra pesquisa sobre o bullying, realizada pelo Instituto Informa no último dia 13 de abril de 2011, entrevistou 830 alunos, de 10 a 16 anos, nas escolas do Rio. O resultado revela que a grande maioria dos alunos - 84,5\% dos entrevistados - já foi vítima $(40,4 \%)$ ou conhece alguém que sofreu agressões físicas ou psicológicas no colégio $(44,1 \%)$.

O levantamento mostra que o problema é mais grave nas unidades municipais. O percentual chega a $90,2 \%$ na rede municipal, contra $82,8 \%$ nos colégios particulares e $72,7 \%$ nos estaduais. Os atos de intimidação e violência ocorrem, principalmente, no ensino fundamental. Por isso a menor incidência na rede estadual, que tem foco no ensino médio.

Além disso, a pesquisa revela que $93,1 \%$ das pessoas que afirmaram já terem sido vítimas de bullying, ou conhecerem alguém que já foi, disseram que não houve qualquer tipo de assistência psicológica às vítimas.

De acordo com a consulta, o problema mais comum são os apelidos pejorativos, que representam $42,7 \%$ dos casos. Deboches coletivos $(18,8 \%)$ e ofensas pessoais $(13,7 \%)$ vêm em seguida. Das vítimas, 57,9\% disseram não ter reagido às agressões e 19,4\% afirmaram ter pensado em vingança.

\footnotetext{
23 Pesquisa disponível em <http//:www.aprendersemmedo.org.br/docs/pesquisa_plan_relatorio_final.pdf >. Acesso em 03 maio 2011.
} 
Ainda, $71 \%$ das pessoas que foram alvo afirmaram terem conseguido superar o trauma.

Conforme o levantamento, as chances de agressão física são maiores nas escolas municipais: $46 \%$. Nas estaduais, o índice é de $40 \%$ e nas particulares, de 33,9\%.

Diretor do Instituto Informa, o sociólogo Fábio Gomes explica que a pesquisa revelou diferenças entre as vítimas de bullying não somente em relação às escolas onde estudam, mas também por idade e sexo. Segundo ele:

"No caso das meninas, constatamos que a agressão mais presente é a verbal. Entre os meninos, é a física" - compara o sociólogo.

Dos 492 alunos de 10 a 14 anos que participaram da pesquisa, 88,4\% confessaram sofrer agressões ou ter colegas que passaram pela situação. $\mathrm{Na}$ faixa etária de 15 e 16 anos, o percentual é de 78,1\%.

Os números mais alarmantes da rede municipal podem ser resultado de outra constatação: nessas escolas, os alunos denunciam mais. Apenas $29,8 \%$ dos estudantes da rede municipal entrevistados pela pesquisa afirmaram não ter comunicado o bullying à direção da escola. Esse percentual é de 58,7\% nas escolas estaduais e de 46,7\% nas particulares.

Já as punições são mais frequentes nas instituições particulares: em 41,3\% dos casos, o agressor sofreu penalidade. Nas unidades do município, só houve castigo para os agressores em 28,9\% das situações. Na rede estadual, em $21,9 \%$.

Ainda segundo a pesquisa, o índice alto de alunos que se dizem vítimas pode estar associado ao nível de conhecimento sobre o problema. 
Do total de crianças e adolescentes abordados pelo Instituto Informa, 61,6\% responderam ter recebido informações nas escolas sobre o bullying ${ }^{24}$.

Por fim, uma pesquisa encomendada pelo Sinesp (Sindicato dos Especialistas de Educação do Ensino Público Municipal de São Paulo), publicada em matéria do Jornal Folha de São Paulo no último dia 02 de maio de $2011^{25}$, entrevistou 475 dos cerca de 5.000 diretores, supervisores e coordenadores das escolas municipais de São Paulo, revelando que os dirigentes têm dificuldades para identificar, em suas unidades, a presença do bullying. O levantamento recém concluído com os servidores constatou que somente $2,7 \%$ dos dirigentes disseram que há bullying em suas escolas.

De acordo com o presidente do Sinesp, João Alberto Rodrigues de Souza, claramente há uma subnotificação dos casos, pois, segundo ele, as pessoas não perceberam as diversas formas de intimidação. "Não é só quando colocam um menino na lata de lixo. Teremos de ampliar a discussão com a rede." Para o presidente, boa parte dos colégios ainda vê intimidações entre os alunos como algo inerente à vida escolar.

O sociólogo Rudá Ricci, responsável pelo estudo, aponta a hora do intervalo como principal exemplo do despreparo das escolas, já que, embora seja um dos momentos em que mais ocorre o bullying, a escola o vê como um momento de descanso da equipe e os alunos ficam entregues à própria sorte. Outra dificuldade, segundo ele, é a condição de trabalho dos dirigentes, pois $31,4 \%$ afirmaram que houve ameaças e $23,6 \%$, agressão verbal. Diante desse quadro, o dirigente fica mais atento à sua defesa e pode deixar a situação dos alunos em segundo plano, afirma Rudá.

\footnotetext{
${ }^{24}$ O Globo. Bullying já afeta $84,5 \%$ dos estudantes no Rio. Mais de $40 \%$ já foram vítimas. Rio de Janeiro, 17 abril 2011. Disponível em <http://oglobo.globo.com/rio/mat/2011/04/17/bullying-jaafeta-84-5-dos-estudantes-no-rio-mais-de-40-ja-foram-vitimas-924263992.asp>. Acesso em 18 abril 2011.

${ }^{25}$ Folha de São Paulo. Dirigentes têm dificuldade em avaliar casos de bullying. São Paulo, p. c4, 02 maio 2011.
} 
Em resposta aos dados levantados pela pesquisa encomendada pelo sindicato dos gestores, a Secretaria Municipal de Educação de São Paulo afirmou que é baixa a ocorrência de violência e agressões entre alunos da sua rede, de modo que o percentual de $2,7 \%$ de gestores que relataram casos de bullying em suas escolas é condizente com o levantamento feito pela secretaria, conforme disse em nota a gestão Gilberto Kassab.

Portanto, observa-se que o fenômeno bullying é um problema mundial, sendo encontrado em toda e qualquer escola, não estando restrito a nenhum tipo específico de instituição: primária ou secundária, pública ou privada, rural ou urbana. Ainda, há que se considerar que, em se tratando de meninas, o bullying costuma se manifestar na forma de terror psicológico e na manipulação de outras meninas contra as "colegas-alvo" (bullying indireto).

\subsection{A judicialização dos conflitos na sociedade contemporânea e o bullying escolar}

Ora, todos nós já fomos vítimas de bullying em algum momento de nossas vidas, ou conhecemos alguém que já o foi. Portanto, por que essa prática, tão natural no cotidiano de crianças e adolescentes desde os tempos mais remotos, atualmente é objeto de tanta atenção por parte da sociedade?

Em primeiro lugar, porque vivemos, nos dias de hoje, em uma sociedade extremamente litigiosa, em que os cidadãos conhecem os seus direitos e vão buscar proteção dos mesmos junto ao Poder Judiciário.

Assim, questões que outrora eram resolvidas no âmbito particular, ou sobre as quais simplesmente se fazia vista grossa, hoje são objeto de ações judiciais, em que os autores procuram a reparação pelos danos suportados, sejam eles de ordem material ou moral. 
Nesse sentido, situações como, por exemplo, a violência contra as mulheres, entram na pauta do Direito e ganham amparo legislativo, deixando de serem vistas como uma prática rotineira, de cunho eminentemente privado (quem não conhece a famosa expressão "em briga de marido e mulher, não se mete a colher"!) ou algo que sempre existiu e que seguirá existindo.

Ou seja, o fato de a violência contra as mulheres ser uma prática muito antiga e comum não impediu que os olhos da sociedade se voltassem para ela apenas nesta última década, ensejando grandes debates e mobilização social, cobrando-se medidas efetivas contra a banalização desse tipo de violência.

É nesse contexto que se insere o estudo do bullying escolar, muito embora a violência no âmbito das escolas seja algo que já existe há muito. Os pais das vítimas, em vez de se conformarem ou se limitarem a solucionar a questão na mesa do Diretor dos estabelecimentos de ensino, hoje se valem do Poder Judiciário para pleitear a reparação pelos prejuízos morais e materiais sofridos por seus filhos, pois tomaram consciência de que, quando as "brincadeiras" normais entre os estudantes extrapolam os limites aceitáveis e revelam comportamentos agressivos, cruéis, propositais e sistemáticos, capazes de deixar sequelas eternas em suas vítimas, além de provocar evasão escolar, é hora de mudar a forma de lidar com elas.

A boa notícia é que a Justiça agora resolveu enfrentar o problema e as condenações começam a surgir pelo país a fora, condenando os responsáveis, em muitos casos os pais dos menores que foram avisados pela escola do comportamento agressivo de seus filhos e se omitiram e, em outros, os estabelecimentos de ensino, pela falha no dever de vigilância que lhes é legalmente imposto, como se verá no capítulo próprio.

As vítimas já não aceitam em silêncio as humilhações, os professores reagem e exigem um ambiente de ensino plural, as escolas investem em 
campanhas de prevenção e a Justiça é acionada cada vez mais para punir os agressores pela falta de limites no bullying. O Brasil demorou quase trinta anos para enfrentar o problema, mas nos últimos três anos, avançamos muito, e com força, para reprimir essas condutas ilícitas ${ }^{26}$.

Corroborando o acima exposto, destaca-se o posicionamento da Organização Mundial de Saúde (OMS) acerca do tema da prevenção da violência no âmbito escolar. Segundo a Organização, a prevenção da violência é um elemento importante em uma escola promotora de saúde, pelas seguintes razões ${ }^{27}$ :

1. A violência afeta o bem-estar e o potencial de aprendizagem de milhões de crianças em todo o mundo.

2. A violência é um problema social e econômico para todas as nações.

3. A violência é aprendida e, por isso, capaz de ser desaprendida.

4. As escolas oferecem recursos apropriados para prevenir e reduzir a violência.

5. A avaliação dos trabalhos de prevenção da violência nas escolas demonstra resultados promissores.

Em função das razões supra citadas, fica clara a importância da prevenção da violência no contexto escolar, tendo em vista as consequências gravíssimas que ela pode vir a acarretar, tanto a nível individual (crianças), como coletivo (nações).

Ademais, na Convenção dos Direitos da Criança (2005), o problema do bullying aparece expresso como uma prioridade para todos os Estados, destacando-se os grupos-alvo mais vulneráveis a serem eleitos como vítimas de tal prática, quais sejam, as crianças com deficiências e as de

\footnotetext{
${ }^{26}$ CALHAU, Lélio Braga. Op. cit. p. 28.

${ }^{27}$ CARVALHOSA, Susana. Op. cit. p. xi.
} 
origem estrangeira, o que, uma vez mais, revela a prática do bullying como expressão da intolerância às diferenças.

Além dos inúmeros massacres motivados pelo bullying acima relatados, destaca-se outro exemplo da hiper divulgação do fenômeno na mídia mundial, através de vídeo disponível no site youtube ${ }^{28}$, que já foi visto por milhões de pessoas em todo o mundo, reavivando o debate sobre o tema.

O vídeo mostra uma cena de aproximadamente quarenta e cinco segundos, em que um garoto obeso (típico alvo dos bullies, por não se enquadrar nos padrões impostos pela sociedade para ser alguém plenamente inserido no grupo) em uma escola da Austrália é agredido por outro garoto, recebendo vários socos na cara, enquanto os demais estudantes olham a cena e se divertem. Entretanto, surpreendentemente, a vítima de bullying revida de forma extremamente violenta, jogando o agressor no chão, quebrando-lhe a perna.

Este episódio foi gravado e postado no youtube, ganhando uma repercussão avassaladora. Em função disso, o garoto Casey Heynes, que passou, aos olhos de milhões de internautas, de vítima de bullying a herói da resistência, foi entrevistado em um programa australiano chamado "A current Affair" ${ }^{29}$. De fato, até mesmo o atirador Wellington Menezes, responsável pelo massacre em Realengo, citou Casey como ícone na luta contra os agressores durante uma das suas gravações divulgadas pela polícia, como já relatado.

Como se pode extrair da entrevista, Casey afirma ter sofrido bullying durante toda a sua vida, em função de sua forma física acima do peso, relatando ter sido sempre provocado, colocado para baixo e atormentado pelos colegas.

${ }^{28}$ Disponível em <http://www.youtube.com/watch?v=0XTZ8Q7dqRM〉. Acesso em 01 abril 2011.

${ }^{29}$ Disponível em <http://www.youtube.com/watch?v=JCejbz22y2w>. Acesso em 01 abril 2011. 
Ao ser perguntado sobre por que as pessoas teriam reagido ao vídeo com tamanho entusiasmo e mostrado tanto apoio a ele, Casey responde que isso se deve ao fato de que "as pessoas sofrem bullying o tempo todo", daí a solidariedade por elas demonstrada.

Segundo Casey, as provocações dos bullies começaram no primeiro ano do colégio, quando os ofensores passaram a chamá-lo de gordo, dar tapas na sua nuca, fazê-lo tropeçar, jogar bexigas com água nele, dentre outras práticas, sendo que tais ações aconteciam todos os dias. De acordo com Casey, ele teria sido escolhido como vítima porque não revidava às agressões.

Para ele, um "dia bom" era aquele em que ninguém o tocava ou provocava, mas isso quase nunca ocorria.

Casey relata que, em razão do bullying sofrido, chegou a pensar em suicídio, atingindo um grau de depressão considerável, mas a relação com a sua irmã o teria feito superar a idéia.

Embora nunca houvesse reagido a um bully da maneira retratada pelo vídeo, Casey confessa que o fez porque "tudo vai se somando em três anos, e a raiva saiu de tudo isso".

Ora, essa fala é emblemática, pois demonstra que aqueles que são expostos ao bullying por um espaço de tempo prolongado vão adquirindo sentimentos negativos e acumulando ódio contra seus agressores, o que pode culminar em massacres como os já analisados ao longo do presente trabalho, já que, como afirmam os especialistas, o bullying pode ser um fator desencadeante de transtornos psiquiátricos latentes nas vítimas.

Após o vídeo, Casey passou a ter quatro páginas no facebook com 200.000 fãs cada uma, além de uma enquete em um site com mais de 150 mil votos e dezenas de vídeos no youtube. Nas palavras do garoto, ele se 
sente bem ao receber as mensagens de pessoas que admiraram sua atitude, pois ele "nunca havia tido tanto apoio na vida".

Alguns autores das mensagens relatam que também são vítimas de bullying, mas nunca tiveram forças para revidar às agressões e chamam Casey de herói, vingador, etc, tornando-o um ícone da resistência para milhares de jovens.

Ao final da entrevista, Casey manda uma mensagem para os jovens do mundo todo que, assim como ele, são vítimas de bullying na escola: "foquem nos dias bons e mantenham o queixo erguido, pois a escola não irá durar para sempre, aguentem firme".

É evidente que a repercussão estrondosa dessa história se deve ao fato de que ela poderia ter ocorrido em qualquer escola do mundo, já que cenas como a mostrada no vídeo acontecem diariamente, revelando, de forma clara, o problema bullying como algo endêmico.

Assim, como ignorar tal fenômeno, ou colocar panos quentes sobre ele, sob os falaciosos argumentos de que é algo natural, típico das relações entre os jovens, e quase que inerente ao cotidiano escolar?

Aceitar essa tese é fechar os olhos para todas as consequências desastrosas que o bullying pode provocar nas suas vítimas, de modo a aniquilar personalidades em formação, incutindo-lhes traumas que serão levados, em maior ou menor grau, para toda a vida.

Afinal, se é certo que a escola é um microcosmos social, o que esperar dos jovens que saem dela para ingressar no mundo adulto se, durante toda a formação escolar, eles tomaram parte em práticas violentas e segregadoras como o bullying, seja como vítimas, agressores, ou espectadores passivos?

Nesse sentido, é salutar o papel das grandes mídias em divulgar as práticas de bullying por todo o mundo, seja através de filmes sobre o 
tema $^{30}$, músicas ${ }^{31}$, vídeos postados no youtube, blogs ou sites em geral sobre o assunto, contribuindo, dessa maneira, para espalhar informações úteis no diagnóstico e combate do bullying.

Dessa forma, tanto os educadores, quanto os pais, podem informar-se e compartilhar experiências sobre o bullying. No que se refere às vítimas, estas percebem que não sofrem sozinhas, identificando-se com outras milhões de crianças ao redor do mundo, também vítimas, o que contribui para diminuir a sensação de isolamento e desamparo que frequentemente as acomete e pode impulsioná-las a tomar atitudes drásticas, como o homicídio em massa e/ou o suicídio.

Os especialistas apontam que, em regra, os bullies, ou agressores, elegem seus alvos buscando justamente aqueles que aparentam maior fragilidade, seja por não se enquadrarem nos modelos impostos pela sociedade para serem plenamente aceitos, seja por não se inserirem em nenhum grupo que lhes ofereça a proteção e o apoio necessários para resistir às agressões. Assim, a sensação de exclusão e de estarem sozinhos no mundo é fundamental para que os bullies tenham sucesso em sua empreitada.

Afinal, diante do contexto de dúvidas, inquietações, angústias, descobertas e emoções exacerbadas, típico da adolescência, o grupo vem a ser o lugar privilegiado do reconhecimento individual e, por isso, objeto afetivo de enorme importância. É no grupo que o sentimento de vínculo do adolescente encontra canal para se expressar na forma de linguagem verbal, física e comportamental ${ }^{32}$.

\footnotetext{
${ }^{30}$ Nesse sentido, dentre outros: Tiros em Columbine, Elefante, Klass, Evil - Raízes do Mal, Bully, Carrie a Estranha, Deixa Ela Entrar, Em um mundo melhor, Bang Bang você morreu, Um grande garoto, Meninas malvadas, Nunca fui beijada.

${ }^{31}$ Dentre outras, veja-se Jeremy, do Pearl Jam.

${ }^{32}$ SILVA, Ana Beatriz Barbosa. Op. cit. p. 65.
} 
Assim, ao terem acesso às informações e trocarem experiências com outras vítimas, os jovens sentem-se mais seguros, menos sozinhos e mais capazes de enfrentar a situação, diminuindo os efeitos do bullying sofrido.

\subsection{O comportamento dos envolvidos no bullying escolar e o papel dos adultos no seu diagnóstico}

A escola é uma microssociedade, sendo certo que, no ambiente escolar, comumente se distinguem as classes dos populares, dos neutros e a dos excluídos.

Os populares são aqueles jovens que possuem um conjunto de qualidades previamente valorizadas pela sociedade e pelo grupo escolar, conferindo-lhes grande poder de influência sobre a maior parte dos estudantes (em regra, possuem boa aparência física, vestem-se bem, possuem corpo atlético, são fisicamente fortes etc.). Os neutros correspondem às meninas e aos meninos que tentam se dar bem com os populares, mas não fazem parte da rede íntima deles. Por fim, os excluídos são aqueles que, de alguma forma, fogem ao padrão considerado "legal" ou aceitável pela comunidade escolar, isto é, são os "diferentes", aqueles que pensam, comportam-se ou vestem-se de forma não usual, tornando-se, em razão disso, os alvos prediletos dos praticantes de bullying ${ }^{33}$.

As reações das vítimas do bullying costumam ser diversas. De acordo com a professora Maria Luísa Bustamante, do Instituto de Psicologia da Universidade do Estado do Rio de Janeiro (Uerj) e chefe do serviço de psicologia aplicada da mesma universidade, elas tanto podem partir para uma atitude mais introspectiva, quanto reagir à violência, assumindo o papel de seus agressores. Segundo a professora, em muitos casos, a vítima do bullying tende a se recolher e a se isolar, tornando-se uma pessoa mais sozinha. Em outros, acontece o oposto, de forma que o

\footnotetext{
${ }^{33}$ Ibid. p.79-80.
} 
bullying pode induzir uma agressividade à vítima, tornando a pessoa mais rebelde e violenta ${ }^{34}$.

No que se refere à forma de lidar com o bullying sofrido, também é possível observar diferentes comportamentos naqueles que são vítimas. De fato, alguns buscam ajuda recorrendo a profissionais da área de saúde mental, outros mostram sua capacidade de serem resilientes, ou seja, elaboram o sofrimento e o transformam em aprendizado, outros, ainda, carregam consigo os traumas da vitimização para a vida adulta, tornando-se adultos ansiosos, inseguros, depressivos ou agressivos, tendendo a reproduzir, em seus relacionamentos profissionais e/ou familiares, a violência que sofreram no ambiente escolar. Finalmente, uma parcela das crianças e adolescentes vítimas de bullying também pode desenvolver transtornos psiquiátricos sérios, sendo o bullying um fator desencadeante para que esses transtornos venham à tona naqueles que já possuiam predisposição genética para desenvolvê-los.

Segundo Dan Olweus, pais e professores devem estar atentos a vários aspectos comportamentais das crianças e dos adolescentes, considerando os possíveis papéis que cada um deles pode desempenhar em um situação de bullying escolar. Assim, identificar os alunos que são vítimas, agressores ou espectadores é de suma importância para que as escolas e as famílias dos envolvidos possam elaborar estratégias e traçar ações efetivas contra o bullying.

Cada personagem envolvido no bullying costuma apresentar um comportamento típico, tanto no ambiente escolar, como em seus lares. Abaixo, listamos comportamentos que podem ser uma pista para o diagnóstico do bullying: ${ }^{35}$

\section{- AS VÍTIMAS}

\footnotetext{
${ }^{34}$ O Globo, Rio de Janeiro, p. 15, 10 abril 2011.

${ }^{35}$ SILVA, Ana Beatriz Barbosa. Op.cit. p. 48-50.
} 
No ambiente escolar

- No recreio, encontram-se frequentemente isoladas do grupo ou perto de algum adulto que possa protegê-las: professor, inspetor, etc.

- Na sala de aula, apresentam postura retraída. Têm extrema dificuldade em perguntar algo ao professor ou emitir sua opinião para os demais alunos. Deixam explícitas suas inseguranças e ansiedades.

- Apresentam faltas frequentes às aulas, com o intuito de fugir das situações de exposição, humilhações e/ou agressões psicológicas e físicas.

- Mostram-se comumente tristes, deprimidas ou aflitas.

- Nos jogos ou atividades em grupo, sempre são as últimas a serem escolhidas.

- Aos poucos vão se desinteressando das atividades e tarefas escolares (isso também inclui perdas constantes de seus pertences, especialmente materiais didáticos).

- Ocasionalmente, nos casos mais dramáticos, apresentam hematomas (contusões), arranhões, cortes, ferimentos, roupas danificadas ou rasgadas.

No ambiente doméstico

- Frequentemente se queixam de dores de cabeça, enjoo, dor de estômago, tonturas, vômito, perda de apetite, insônia. Todos esses sintomas tendem a ser mais intensos no período que antecede o horário de as vítimas entrarem na escola.

- Mudanças frequentes e intensas de estado de humor, explosões repentinas de irritação ou raiva. 
- Geralmente, não têm amigos ou bem poucos, que preferem não frequentar sua casa ou compartilhar outras atividades livres. Essa situação fica evidenciada pela escassez de telefonemas, e-mails, torpedos, convites para festas, passeios, excursões ou viagens com o grupo escolar.

- Passam a gastar mais do que o habitual na cantina da escola ou em compras de objetos diversos, com o intuito de presentar os outros, a fim de evitar as perseguições.

- Apresentam desculpas, inclusives sintomas de doenças físicas, com o intuito de faltar às aulas. De fato, afirmam os especialistas que o estresse vivenciado pelas vítimas de bullying ocasiona baixa imunidade fisiológica, debilitando o organismo como um todo, predispondo o jovem a várias enfermidades.

- Apresentam-se irritadas, ansiosas, tristes ou deprimidas, sonolentas durante o dia e com um ar de infelicidade permanente.

- Tornam-se descuidadas com tudo que esteja relacionado aos afazeres escolares.

\section{- OS AGRESSORES (BULLIES)}

No ambiente escolar

- Começam com brincadeiras de mau gosto, que rapidamente evoluem para gozações, risos provocativos, hostis e desdenhosos.

- Colocam apelidos pejorativos e ridicularizantes, com explícito propósito maldoso.

- Insultam, difamam, ameaçam, constrangem e menosprezam alguns alunos.

- Dão ordens, dominam e subjugam seus pares. 
- Pegam materiais escolares, dinheiro, lanches e quaisquer pertences de outros estudantes sem consentimento, ou até sob coação.

No ambiente doméstico

- Apresentam, habitualmente, atitudes hostis, desafiadoras e agressivas com relação aos pais, irmãos e empregados.

- Não respeitam hierarquias, como a diferença de idade ou de força física entre seus familiares.

- Mostram-se bastante hábeis em manipular as pessoas para se livrarem das confusões em que se envolveram. Costumam mentir sem qualquer constrangimento e de forma convincente quando questionados sobre suas atitudes hostis.

- Muitos bullies se portam em casa como se nada de errado estivesse acontecendo, além de contestarem todas as observações negativas que os pais recebem por parte da escola, dos irmãos ou dos empregados domésticos.

Estudos apontam que os bullies tendem a pertencer a famílias que são caracterizadas como tendo pouco carinho ou afeto, com problemas em expor seus sentimentos e, normalmente, classificam-se como unidades familiares em que existe uma maior distância emocional entre seus membros. Ademais, os pais dos agressores costumam criticar seus filhos, sem nunca elogiá-los, negligenciam em ensinar aos menores que agressão não é aceitável, tendem a usar disciplina inconsistente, têm pouco controle sobre onde os filhos estão ao longo do dia e, por vezes, têm estilos de disciplina muito punitiva e rígida, priorizando os castigos físicos ${ }^{36}$.

A psiquiatra Ana Beatriz Barbosa Silva aponta que distinguir os agressores que podem ser dissuadidos desse papel e transformados em

\footnotetext{
${ }^{36}$ CARVALHOSA, Susana. Op. cit. p. 21.
} 
aliados no combate à violência escolar daqueles que já exibem, desde muito cedo, uma natureza desprovida de afetividade, é tarefa difícil.

A partir dessa distinção, torna-se possível elaborar estratégias escolares e sociais que possam ajudar a recuperar os jovens que se comportam de maneira agressiva e violenta em função de circunstâncias desfavoráveis nas quais estejam envolvidos. Tais jovens possuem o sentimento de culpa, remorso ou arrependimento diante de suas ações, o que revela que tais comportamentos são transitórios.

Por outro lado, os agressores que não apresentam nenhum sinal de culpa em relação às suas condutas são portadores do denominado transtorno da conduta, caracterizado por um padrão repetitivo e persistente de condutas antissociais, podendo vir a tornarem-se os psicopatas da vida adulta. Para os jovens com esse perfil, adverte a psiquiatra que regras e limites muito claros devem ser estabelecidos e fiscalizados para se evitar comportamentos manipuladores e violação das normas sociais ${ }^{37}$.

Finalmente, em se tratando dos espectadores, Cleo Fante e José Augusto Pedra explicam que eles representam a maioria dos alunos de uma escola. Eles não sofrem e nem praticam bullying, mas sofrem as suas consequências por presenciarem constantemente as situações de constrangimento vivenciadas pelas vítimas. Segundo os autores, muitos espectadores repudiam as ações dos agressores, mas nada fazem para intervir. Outros as apoiam e incentivam dando risadas, consentindo com as agressões. Outros, ainda, fingem se divertir com o sofrimento das vítimas, como estratégia de defesa. Esse comportamento é adotado como forma de proteção, pois temem tornarem-se as próximas vítimas. ${ }^{38}$

Diante do exposto, cabe aos adultos o desenvolvimento de um olhar atento para as atitudes dos jovens que possam exprimir um comportamento

\footnotetext{
${ }^{37}$ SILVA, Ana Beatriz Barbosa. Op. cit. p. 50.

${ }^{38}$ FANTE, Cleo; PEDRA, José Augusto. Bullying escolar: perguntas e respostas. Porto Alegre: Artmed, 2008. p. 61.
} 
defensivo em relação às dificuldades psicológicas vividas no dia a dia, seja através de uma postura reativa, com atitudes agressivas, seja através de uma postura passiva, com comportamentos submissos, canalizando, de forma autodestrutiva, a agressividade que lhes é imposta por terceiros.

Segundo os especialistas, se os jovens apresentam irritabilidade excessiva, isolam-se no quarto, passam muito tempo em frente ao computador, não têm amigos e apresentam seus pertences constantemente danificados, é muito provável que estejam sendo vítimas de bullying.

O filme dinamarquês "Em um mundo melhor" (no original, Haevnen), do ano de 2010, mostra a história de um menino, Elias, que sofre perseguição no colégio de um garoto maior que ele e "líder" dos demais, em função de sua aparência física, já que era magro, usava aparelho nos dentes e aparentava ser frágil, destacando-se dos outros meninos, fisicamente mais desenvolvidos. Constantemente hostilizado, ele era agredido, insultado verbalmente, tinha seu material danificado, o pneu de sua bicicleta esvaziado e era excluído dos demais alunos.

Esse quadro se perpetua até que um aluno novo, Christian, chega à escola e, ao presenciar o bullying sofrido por Elias, decide defender o garoto. Porém, em retaliação à ação, é agredido pelo bully. Como vingança, Christian dá uma surra no agressor e o ameaça com uma faca.

Ao ser questionado pelo pai do porquê de ter agido com tamanha violência, Christian prontamente responde que em todas as escolas é assim; os novos só conseguem se impor diante dos agressores se mostrarem, desde o início, que não apanham impunemente e podem revidar à altura, sob pena de os bullies pensarem que poderão sempre bater nele.

Assim, seguindo esse código tácito de conduta que norteia o comportamento dos jovens estudantes, Christian se viu obrigado a vingar-se do agressor de maneira violenta, para que este passasse a respeitá-lo e, assim, deixasse a ele e a seu amigo, Elias, em paz. De fato, após agir com 
violência e impor-se diante do agressor, este passa a respeitar Christian e inclusive a buscar uma aproximação com o garoto.

Tal trama mostrada pelo filme em questão evidencia que as vítimas do bullying são eleitas justamente em função de suas dificuldades de se impor ao grupo, tanto física, quanto verbalmente, consentindo, caladas, com a agressão sofrida, o que as torna alvos fáceis e comuns dos ofensores.

Ademais, a exposição contínua à prática do bullying acaba por isolálas dos demais estudantes, de modo que, em geral, não têm amigos ou colegas solidários, o que as torna alvos ainda mais vulneráveis.

Além disso, a vergonha que sentem em função de sua vitimização no colégio faz com que a maior parte das vítimas não conte aos pais que sofre bullying, por acharem que isso irá expor suas fraquezes aos responsáveis, ou que os pais irão considerá-las covardes, indefesas, etc. e, por isso, preferem sofrer caladas.

No filme ora comentado, Elias sempre chegava transtornado do colégio em casa, porém, embora sua mãe perguntasse o motivo de seu estado, ele se negava a contar o bullying sofrido e descontava toda a frustração e raiva que sentia em função da perseguição que lhe era dirigida na genitora, respondendo-a de forma ríspida e agressiva e se isolando no quarto.

O filme mostra a importância da presença dos pais na vida daqueles que estão envolvidos na prática do bullying, seja como agressores ou como vítimas, para que eles sejam capazes de notar os sinais que seus filhos dão ao chegarem em casa após o colégio, ou antes de ir para a aula.

Ora, se os pais não estão presentes em casa para acompanhar o momento de chegada de seus filhos da escola, bem como o comportamento destes no lar, o diagnóstico do bullying será muito pouco provável, ou só virá quando a situação já estiver insustentável e as consequências já forem 
irreversíveis. Além disso, a presença dos pais é indispensável também para que, uma vez diagnosticado o problema, eles possam ir até a escola expor a situação aos professores, para que ambos possam atuar conjuntamente na busca de uma solução.

Ao longo do filme, os pais de Elias vão até o colégio e expõem a perseguição que seu filho vem sofrendo para os professores da turma dele, mas estes se omitem e não admitem o bullying praticado nas dependências da escola contra o menino. Os professores afirmam que se trata apenas de brincadeiras normais entre os alunos, chegando a apontar a ausência do pai, que é médico e trabalha parte do tempo na África, bem como a separação recente do pai e da mãe como causadoras do sofrimento do filho. A escola só passa a atuar quando a situação se agrava ao ponto de os alunos envolvidos no bullying brigarem com uma faca dentro da escola, ferindo gravemente um deles, o que atrai inclusive a polícia para o caso.

A postura omissa adotada pela escola no filme é muito frequente nos casos de bullying da vida real, havendo inúmeros relatos de pais que alegam ter buscado a escola e exposto à ela a situação de bullying vivenciada por seus filhos nas dependências da instituição, sem encontrar, contudo, nenhum amparo, tendo que lidar com o problema sozinhos, além de serem acusados de estar exagerando e reagindo de forma desproporcional a situações corriqueiras e banais experimentadas pelos jovens nas relações dentro da escola.

É evidente que esperar até que a situação tome proporções irreversíveis não é recomendável, sendo fundamental a atuação conjunta dos pais e da escola ao primeiro sinal do bullying, para que as consequências desastrosas de tal prática possam ser evitadas. Para tanto, é mister que os pais estejam atentos aos sintomas demonstrados por seus filhos quando estes estão envolvidos com o bullying e, além disso, que tanto a escola, quanto os pais, encarem a situação com a seriedade necessária, em 
vez que fechar os olhos e achar que a prática do bullying é algo normal e corriqueiro entre os alunos.

No site da ONG PLAN, encontra-se disponível um teste para que os pais saibam se seus filhos estão sofrendo violência escolar, através de um questionário com perguntas relacionadas à conduta da criança ${ }^{39}$. Iniciativas como essa são salutares para um diagnóstico precoce do bullying, evitando, assim, que a situação adquira maior gravidade.

Em relação ao cyberbullying, aponta Ana Beatriz Barbosa Silva que os pais devem reparar o comportamento dos filhos quando eles estão fazendo uso do computador: quantas horas por dia eles ficam "navegando"? Durante esse período, eles costumam ter reações como xingar, chorar, gargalhar, ou ficam muito quietos? É comum tentarem esconder a tela do computador quando alguém entra em seu quarto?

Além disso, o comportamento fora da internet também deve ser bem observado: evitam ir à escola? Dormem demais? Tiveram perda ou ganho de apetite? Apresentam insônia, explosões de raiva ou crises de choro?

Aduz a psiquiatra que, especialmente nos adolescentes, que estão vivenciando uma fase de profundas mudanças cerebrais, os ataques de bullying virtual podem se constituir em um fator desencadeante de diversas doenças mentais naqueles jovens que já tinham uma predisposição genética para tanto, sendo certo que os fatores educacionais e culturais que cada um vivenciou são determinantes para o desencadeamento ou não de tais doenças.

Assim que perceberem as primeiras alterações significativas no comportamento de seus filhos, os pais devem buscar ajuda especializada, pois, quanto mais cedo começar o tratamento, maiores serão as chances de

\footnotetext{
${ }^{39}$ Disponível em <http://www.aprendersemmedo.org.br/?p=faca-o-teste>. Acesso em 03 maio 2011.
} 
reverter totalmente esses transtornos, reduzindo o risco de sequelas graves e permanentes na vida adulta ${ }^{40}$.

\section{8. Consequências psíquicas e comportamentais do bullying}

Além de os bullies costumarem escolher um aluno-alvo que se encontra em franca desigualdade de poder, geralmente este também já apresenta uma baixa autoestima. Dessa maneira, a prática de bullying agrava o problema preexistente, podendo abrir quadros graves de transtornos psíquicos e/ou comportamentais que, muitas vezes, trazem prejuízos irreversíveis às vítimas. Assim, muitos adultos ainda experimentam aflições intensas advindas de uma vida estudantil traumática.

Dentre as consequências psíquicas e comportamentais mais comuns nas vítimas do bullying, pode-se destacar ${ }^{41}$ :

- Sintomas psicossomáticos: cefaleia, cansaço crônico, insônia, dificuldades de concentração, náuseas, diarréia, boca seca, palpitações, alergias, crise de asma, sudorese, tremores, sensação de "nó" na garganta, tonturas ou desmaios, calafrios, tensão muscular, formigamentos.

- Transtorno do pânico: Caracteriza-se pelo medo intenso e infudado, que parece surgir do nada, sem qualquer aviso prévio.

-Fobia escolar: Caracteriza-se pelo medo intenso de frequentar a escola, ocasionando repetência por faltas, problemas de aprendizagem e/ou evasão escolar.

- Fobia social: Também conhecida por timidez patológica, gera ansiedade excessiva e persistente, temor exacerbado de se sentir o centro das atenções ou de estar sendo julgado e avaliado negativamente.

\footnotetext{
${ }^{40}$ SILVA, Ana Beatriz Barbosa. Op. cit. p.137-138.

${ }^{41}$ Ibid. p.25-31.
} 
- Depressão: Atualmente, os estudos sugerem um alto nível de incidência de sintomas depressivos na população escolar. O número de suicídios entre os adolescentes vem apresentando aumento significativo, configurando-se em uma das principais causas de morte nessa faixa etária ${ }^{42}$.

- Anorexia e bulimia

- Transtorno obsessivo-compulsivo (TOC): Momentos de forte estresse, ocasionados, por exemplo, pelo bullying sofrido, podem abrir um quadro de TOC em pessoas com predisposição genética, ou intensificar o problema preexistente.

- Transtorno do estresse pós-traumático (TEPT): Observa-se um número crescente de TEPT em adolescentes que estiveram envolvidos com o bullying.

Dessa forma, além de o bullying ser uma prática extremamente maléfica para a convivência entre os estudantes, ele pode levar a quadros clínicos que demandam cuidados médicos e psicológicos para que sejam superados, o que, frise-se, pode nunca efetivamente ocorrer, de forma que a vítima do bullying carregará, para sempre, as sequelas de tal prática, daí sua gravidade.

A jurisprudência é pacífica em classificar os gastos médicos realizados em decorrência da vitimização no bullying como danos materiais, passíveis, portanto, de serem indenizados pelos responsáveis.

\subsection{Os protagonistas do bullying escolar e a inserção do fenômeno no contexto da sociedade contemporânea}

${ }^{42}$ Segundo dados do Mapa da Violência/2011, os índices de suicídios cresceram 17\% na população jovem na década de 1998 a 2008 . Disponível em <http://ultimosegundo.ig.com.br/brasil/taxa+de+suicidio+no+brasil+sobe+17+em+10+anos/n1238 111374748.html>. Acesso em 12 abril 2011. 
"Talvez não exista pior privação, pior carência, que a dos perdedores na luta simbólica por reconhecimento, por acesso a uma existência socialmente reconhecida, em suma, por humanidade".

Pierre Bourdieu, Meditações pascalianas $^{43}$

Como já afirmado ao longo do presente trabalho, as vítimas típicas do bullying escolar são os alunos que apresentam pouca habilidade de socialização. Dessa forma, em geral são tímidas ou reservadas, de modo a não conseguirem reagir aos comportamentos provocadores e agressivos dirigidos contra elas. Normalmente, são mais frágeis fisicamente ou apresentam algum traço que as destaca da maioria dos alunos: são gordinhas ou magras demais, altas ou baixas demais, deficientes físicos, são de raça, credo, condição socioeconômica ou orientação sexual diferentes, usam roupa fora de moda, etc ${ }^{44}$.

Nesse sentido, percebe-se que o bullying é um fenômeno extremamente ligado aos padrões impostos por determinados grupos, ou seja, trata-se de enquadrar-se plenamente neles ou não. Assim, aqueles que não se inserem na lógica do grupo que “domina" são marginalizados, segregados e excluídos. Em regra, essas crianças ou adolescentes "estampam" facilmente as suas inseguranças na forma de extrema sensibilidade, passividade, submissão, falta de coordenação motora, baixa autoestima, ansiedade excessiva e inaptidão para se expressar. Desse modo, por apresentarem dificuldades significativas de se impor ao grupo, tanto física, quanto verbalmente, tornam-se alvos fáceis e comuns dos ofensores.

\footnotetext{
${ }^{43}$ BOURDIEU, Pierre. Apud BAUMAN, Zygmunt. Vida para Consumo: a transformação das pessoas em mercadoria. Rio de Janeiro: Jorge Zahar Ed., 2008. p. 7.

${ }^{44}$ SILVA, Ana Beatriz Barbosa. Op. cit. p.37-38.
} 
Diante desse cenário, o estudo do bullying, como um fenômeno multifacetado e complexo, exije o esforço de inserí-lo no contexto da sociedade hodierna, de forma a revelar quais valores tal prática afirma.

Para tanto, em primeiro lugar, é preciso situar o bullying escolar como uma prática protagonizada por jovens.

$\mathrm{Na}$ atualidade, a imagem da juventude está marcada, ao mesmo tempo, pela ambiguidade e pela incerteza. De um lado, a juventude é sempre exaltada pelas potencialidades existenciais que condensa e, de outro, a condição jovem caracteriza-se por sua posição de suspensão no espaço social, que se materializa pela ausência de seu reconhecimento social e simbólico. Assim, a incerteza é o que se delineia efetivamente como o futuro real para os jovens, em todos os quadrantes do mundo.

Ademais, a construção do modelo neoliberal de economia internacional acabou por fazer com que os jovens se inserissem mais tardiamente no mercado de trabalho, o que contribuiu para que o tempo de duração da adolescência se alongasse bastante, de modo que os jovens ficaram fora do espaço social formal, lançados numa terra de ninguém. Dessa forma, graças à ausência de inserção no mercado de trabalho, a juventude foi destituída de reconhecimento social e simbólico, restando-a, apenas, o corpo e a força física como meios de distinção social.

De acordo com Joel Birman, psicanalista e professor do Instituto de Psicologia da UFRJ, é nesse registro que se deve inscrever a disseminação do bullying na contemporaneidade. Segundo ele, a provocação e a violência entre os jovens e crianças é uma prática social antiga. O que é novo, contudo, é a ausência de uma autoridade que possa funcionar como mediação no combate.

Nesse sentido, aduz Birman que, pela luta e pelo combate agonístico com os colegas considerados mais frágeis, os "valentões” preparam-se já para o futuro, para a selva do mundo neoliberal, restringindo o campo da 
competição pelo estabelecimento da hierarquia entre os corpos e por meio da serialização da força existente entre eles ${ }^{45}$.

Frank C. Sacco, doutor em psicologia e autor do Preventing Bullying and School Violence, lançado recentemente nos Estados Unidos, define o bullying como um show e um ato psicológico repetido na frente de uma plateia. Segundo ele, surtos letais que provocam tiroteios em escolas, como os já relatados ao longo deste trabalho, são atos simbólicos nascidos da vergonha, sendo certo que, em regra, existe um componente de "anjo vingador" no simbolismo. Assim, o fato de o atirador ir para a escola é um sinal de que seu simbolismo acarretou experiências na escola.

De acordo com o especialista, os protagonistas do bullying só irão praticá-lo se os espectadores permitirem, já que o agressor e a vítima fazem parte de um show (on-line ou na escola), e os espectadores estão em toda parte $^{46}$.

Zygmunt Bauman, importante sociólogo polonês, afirma que o ambiente existencial que se tornou conhecido como "sociedade de consumidores" se distingue por uma reconstrução das relações humanas a partir do padrão, e à semelhança, das relações entre os consumidores e os objetos de consumo ${ }^{47}$.

Dessa forma, argumenta Bauman que, nesta sociedade de consumidores, ninguém pode se tornar sujeito sem, primeiro, virar mercadoria e ninguém pode manter segura sua subjetividade sem reanimar, ressuscitar e recarregar de maneira perpétua as capacidades esperadas e exigidas de uma mercadoria vendável.

Desse modo, a subjetividade do sujeito concentra-se num esforço sem fim para ela própria se tornar e permanecer uma mercadoria vendável, de

\footnotetext{
${ }^{45}$ BIRMAN, Joel. Ser ou não ser. Revista Cult. São Paulo, n. 157, p. 25 - 27, 2011.

${ }^{46}$ PAOLA, Fernanda. Anjos vingadores. Revista Cult. São Paulo, n. 157, p. 28 - 29, 2011.

${ }^{47}$ BAUMAN, Zygmunt. Op. cit. p. 19.
} 
maneira que a característica mais proeminente da sociedade de consumidores é a transformação dos consumidores em mercadorias.

Ora, nesse contexto, todos almejam tornar-se uma mercadoria notável, notada e cobiçada; uma mercadoria comentada, que se destaca da massa de mercadorias, impossível de ser ignorada, ridicularizada ou rejeitada. Segundo o autor, nesta sociedade de consumidores, "tornar-se uma mercadoria desejável e desejada é a matéria de que são feitos os sonhos e os contos de fadas" 48 .

Aplicando-se tal lógica, magistralmente explicitada por Bauman, à prática do bullying, constata-se que aqueles que falham na tarefa de tornarem-se mercadorias com algum valor de mercado, em função de não possuirem as qualidades valorizadas pela sociedade de consumidores, são as vítimas mais comuns do bullying. Ou seja, trata-se de discriminar, penalizar e vitimizar os que não possuem a qualidade de mercadoria vendável, por fugirem aos padrões impostos, o que revela a mercantilização da sociedade, bem como a intolerância às diferenças.

Nesse sentido, Arlie Russel Hochschild resume o principal "dano colateral" perpetrado no curso da invasão consumista na expressão “materialização do amor”. Segundo ele:

"O consumismo atua para manter a reversão emocional do trabalho e da família. Expostos a um bombardeio contínuo de anúncios graças a uma média diária de três horas de televisão (metade de todo o seu tempo de lazer), os trabalhadores são persuadidos a "precisar" de mais coisas. Para comprar aquilo de que agora necessitam, precisam de dinheiro. Para ganhar dinheiro, aumentam sua jornada de trabalho. Estando fora de casa por tantas horas, compensam sua ausência do lar com presentes que custam dinheiro. E assim continua o ciclo". ${ }^{49}$

Cria-se, assim, um ambiente familiar aparentemente harmônico, no qual a função mais importante dos pais é ser um ponto de referência material e financeiro capaz de simular uma afetividade difícil de ser exercida.

\footnotetext{
${ }^{48}$ Ibid. p. 22.

${ }^{49}$ HOCHSCHILD, Arlie Russel. Apud BAUMAN, Zygmunt. Op. cit p.153.
} 
Complementa Bauman o raciocínio acima transcrito afirmando que a ausência física do cenário do lar torna os trabalhadores, homens e mulheres, impacientes com os conflitos que a vida familiar sob um mesmo teto inevitavelmente provoca. Nesse contexto, ocupados em ganhar mais dinheiro em função de coisas que crêem precisar para serem felizes, os indivíduos têm menos tempo para a empatia mútua e para as negociações necessárias ao convívio.

Assim, segundo Bauman, tal dinâmica aciona um círculo vicioso, já que, quanto mais obtêm êxito em "materializar" as relações afetivas, menores são as oportunidades para o entendimento entre os envolvidos.

Nesse sentido, a indiferença dos pais e a ausência destes no ambiente doméstico equivale a uma renúncia oficial e perigosa no papel essencial que lhes cabe em relação aos filhos, o de educá-los, sendo imprescindível, para tanto, confrontar os filhos com regras e limites, delimitando, de forma clara, as fronteiras entre o que se pode e o que não se pode fazer.

Dessa forma, sustenta Bauman que a busca por prazeres individuais, articulada pelas mercadorias oferecidas hoje em dia - uma busca guiada e a todo tempo redirecionada e reorientada por campanhas publicitárias sucessivas - fornece o único substituto aceitável para o calor humano de cuidar e ser cuidado pelos mais próximos e queridos no $1 \mathrm{lar}^{50}$.

É evidente que os valores prezados pela sociedade de consumidores contemporânea estão intimamente ligados ao fenômeno bullying.

De fato, a transformação das pessoas em mercadoria, tal como sustentado por Bauman, acaba por eleger um padrão inatingível a ser alcançado pelos indivíduos, para que estes se tornem mercadorias com algum valor de mercado no jogo de trocas simbólicas. Este padrão exerce uma influência ainda maior nos jovens, sobretudo pela pressão que a mídia faz sobre eles.

\footnotetext{
${ }^{50}$ BAUMAN, Zygmunt. Op. cit. p. 154.
} 
Aqueles que se afastam do modelo de "mercadoria ideal" imposto são excluídos, marginalizados e tendem a ser as vítimas ideais do bullying, justamente por não se encaixarem no referido padrão. Afinal, em uma sociedade em que as pessoas são medidas por seu "valor de mercado", aqueles que não possuem atrativos suficientes para serem vendáveis não têm lugar e seu destino é a exclusão, tal qual ocorre com um bem rejeitado no interior de uma loja.

Nesse contexto, a internalização dos sentimentos negativos gerados pela rejeição explícita advinda do bullying se manifesta em forma de adoecimentos psíquicos, cujas consequências podem levar a uma vida adulta caótica e sofrível.

O "diferente", ou seja, aquele que não possui os atributos valorizados pela sociedade de consumidores, é rechaçado em sua diversidade, humilhado e ridicularizado por aqueles que se consideram superiores, simplesmente pelo fato de se enquadrarem no modelo imposto.

O bully, ou agressor, procura afirmar a sua inserção plena na sociedade de consumidores, ou seja, o seu pertencimento ao grupo de "vencedores" na batalha simbólica por status e reconhecimento, apontando a sua diferença em relação à vítima, buscando diminuí-la e classificar a diversidade desta como inferioridade.

Daí a origem da segregação e da agressão no ambiente escolar, em regra dirigida contra os mais fracos, isto é, aqueles considerados mercadorias sem valor de mercado, reflexo da internalização, por parte dos jovens, dos valores pregados pela mídia da sociedade de consumidores, valores estes tão caros ao desenvolvimento das crianças e adolescentes.

Ademais, a necessidade crescente de bens de consumo, induzida pelas campanhas publicitárias e pelo discurso midiático, leva os homens e mulheres, notadamente, os pais das vítimas e dos agressores na prática do bullying, a se ausentarem do ambiente familiar por cada vez mais tempo, a 
fim de alcançarem o sucesso material necessário à aquisição dos bens ditos tão necessários.

Como forma de compensar esta ausência, procuram presentear seus filhos com bens, crendo, de forma sincera, que o afago material tem o condão de substituir o diálogo e o afeto, imprescindíveis para um desenvolvimento saudável da criança e do adolescente.

Como já salientado anteriormente, a atuação dos pais é fundamental para o combate do bullying, já que estes devem estar sempre atentos ao comportamento de seus filhos e observar os sinais que eles demonstram quando estão sofrendo ou praticando o bullying no ambiente escolar. Dessa maneira, é fundamental que os genitores estejam presentes na vida de seus filhos, para que possam diagnosticar o problema e buscar o tratamento adequado para ele.

Ocorre que, se os pais estão todo o tempo ocupados com o trabalho, não poderão acompanhar a ida e a volta dos filhos da escola, tampouco observar o comportamento deles dentro de casa, durante o tempo de lazer, o que fará com que o bullying vivenciado por eles passe desapercebido, o que contribui para agravar, ainda mais, a sensação de desamparo da criança.

Ademais, constata-se que uma grande parcela de pais age de forma excessivamente tolerante com seus filhos, adotando a política do "deixa pra lá" diante de comportamentos francamente transgressores. Assim, tais pais costumam fingir que nada ocorreu, demonstram uma postura de falso entendimento ou censuram seus filhos de maneira tão débil que suas reprimendas não são obedecidas por eles.

As razões para tal permissividade por parte dos pais são diversas, podendo apontar-se o fato de os responsáveis quererem evitar desavenças familiares ou como forma de compensar o período em que estão distantes dos filhos por motivos profissionais, buscando aliviar o sentimento de culpa que carregam por não acompanharem a vida dos seus descendentes através 
de uma excessiva tolerância. $\mathrm{O}$ resultado desta postura é que, desde muito cedo, as crianças se habituam a fazer tudo o que querem e impõem-se, de forma autoritária e tirana, perante os pais sobrecarregados e exaustos.

\section{10. Prevenção e soluções para o bullying escolar}

Segundo Susana Carvalhosa, para uma política anti-bullying exitosa, são necessários três pré-requisitos:

1. Identificação - reconhecimento de que o problema existe.

2. Clareza - clima onde o bullying possa ser discutido.

3. Domínio - pais/encarregados da educação, educadores/professores e alunos estejam envolvidos na política anti-bullying.

Afirma a autora que a política de não tolerância da violência deve estar implícita no regulamento da escola, com o envolvimento e a colaboração de toda a comunidade educativa.

Ademais, segundo ela, é necessário conscientizar docentes, funcionários, alunos e familiares relativamente ao problema, confirmar e caracterizar os abusos e as intimidações e determinar a sua magnitude e as suas implicações, com o fim de viabilizar a elaboração de projetos de intervenção adequados às diferentes realidades, os quais devem estar integrados no Projeto Educativo da Escola.

Em síntese, Susana Carvalhosa recomenda que as escolas:

- Façam uma avaliação do problema na própria escola, para determinar a sua gravidade, administrando um questionário a professores, estudantes e pais;

- Promovam o conhecimento sobre as atividades de bullying; 
- Desenvolvam um código de conduta para os alunos, utilizando sanções não hostis e não físicas;

- Envolvam os pais, oferecendo-lhes programas de educação;

- Incentivem uma boa comunicação entre os pais e os educadores, de modo a estabelecer e reforçar as regras, a fim de demonstrar que o bullying não será tolerado;

- Encorajem o pessoal da escola a identificar os estudantes envolvidos no bullying, de modo a articular as características comportamentais e psicológicas associadas à prática;

- Responsabilizem os educadores para monitorar e supervisionar os estudantes nos recreios e em outras áreas onde o bullying possa ocorrer;

- Registrem oficialmente os incidentes de bullying;

- Envolvam alunos e professores para que estes tomem parte na avaliação do êxito ou não da escola em lidar com os problemas associados ao bullying;

- Providenciem serviços de aconselhamento para os bullies e para as vítimas. $^{51}$

Ademais, estudiosos do tema apontam que a chave para a atuação dos adultos diante de um quadro de bullying caracterizado é estimular o diálogo, a construção de vínculos afetivos fortes, o desenvolvimento de uma reflexão crítica, o incentivo à participação familiar e escolar e a implementação de regras e limites muito bem definidos.

O psiquiatra e escritor Gustavo Teixeira, com ampla experiência no tratamento de casos de bullying, acredita que a melhor fórmula para atacar o problema é a união entre a família e a instituição de ensino. Segundo ele:

\footnotetext{
${ }^{51}$ CARVALHOSA, Susana. Op. cit. p. 35-36.
} 
-"Não é algo que vá se resolver por lei ou por decreto. O que se mostra eficiente é a parceria entre o colégio e os pais, além de uma política pública sistemática, que hoje não existe"

Nesse sentido, é altamente recomendável que a escola desempenhe um papel atuante na redução desse fenômeno, traçando estratégias voltadas tanto para a prevenção quanto para o combate, nos casos já instalados.

Ademais, é imprescindível o estabelecimento de parcerias com instituições públicas ligadas à educação e ao direito, tais como os Conselhos Tutelares, as Delegacias da Criança e do Adolescente, as Promotorias Públicas, Varas da Infância e Juventude e as Promotorias da Educação. O somatório de forças é capaz de multiplicar a eficácia e a rapidez das medidas tomadas contra o problema.

Uma das soluções propostas pela Secretaria municipal de Educação do Rio de Janeiro é um projeto de Justiça Restaurativa, que será implantado a partir de maio de 2011 em 151 unidades escolares. A idéia é, por exemplo, que um aluno que tenha feito uma charge humilhando um colega faça um poema com um conteúdo oposto.

Em São Paulo, a gestora de recursos humanos Cristiane de Almeida criou, em 2009, uma ONG para combater o bullying, depois que o filho, hoje com 13 anos, passou quatro anos sofrendo agressões físicas e verbais na escola municipal Rivadávia Marques Junior. Segundo Cristiane, a escola alegava que se tratava de uma instituição de periferia, logo, as agressões eram normais, coisa de criança. A "Educar Contra o Bullying" faz palestras para alunos, professores, pais e gestores, a fim de orientá-los a reconhecer o problema.

No Rio de Janeiro, um grupo de seis jovens decidiu montar uma mistura de palestra e peça teatral chamada "Bullying - Não quero ir pra escola". O motivo foram as histórias que os próprios atores viveram. A peça tem rodado as escolas brasileiras e a repercussão tem sido muito 
boa, segundo os atores. Em uma das encenações, um bully, de 16 anos, teria reconhecido seu "pecado" na frente da turma e pedido desculpas à vítima ${ }^{52}$.

Portanto, percebe-se que aqueles que já vivenciaram o bullying, seja pessoalmente, seja através de algum familiar, têm muito a ensinar a quem ainda não é familiarizado com esse tipo de violência escolar. Dessa forma, iniciativas como as acima descritas revelam-se extremamente eficazes na divulgação do fenômeno bullying, o que é essencial para o seu combate.

${ }^{52}$ O Globo. Gente que sofreu ou praticou bullying ensina como dar a volta por cima. Rio de Janeiro, 10 maio 2011.

Disponível em <http://oglobo.globo.com/educacao/mat/2011/05/09/palestra-criada-por-gente-que-sofreu-oupraticou-bullying-ensina-como-dar-volta-por-cima-924421469.asp>. Acesso em 10 maio 2011. 


\section{A RESPONSABILIDADE DOS PAIS E DA INSTITUIÇÃO DE ENSINO PELOS ATOS DE BULLYING PRATICADOS POR MENORES NO ÂMBITO DAS ESCOLAS QUE ACARRETEM DANOS MORAIS E MATERIAIS ÀS VÍTIMAS}

Neste capítulo, tratar-se-á da questão da responsabilidade dos pais e da instituição de ensino pelos atos caracterizadores de bullying escolar praticados por menores no âmbito das escolas, quando causadores de danos morais e materiais às vítimas.

Para tanto, abordar-se-á o tema da responsabilidade civil por fato de terceiro, apontando os pressupostos para a sua incidência, tanto no que se refere à responsabilidade dos pais pelos atos dos filhos menores que estiverem sob sua autoridade e em sua companhia, quanto no que tange à responsabilidade das instituições de ensino pelos atos dos educandos.

Por fim, analisar-se-á como a jurisprudência vem se posionando sobre o tema, com o intuito de evidenciar a necessidade de atuação conjunta dos pais e da instituição de ensino no combate ao bullying escolar.

\subsection{O bullying é proibido pelo ordenamento jurídico brasileiro}

Em primeiro lugar, cumpre esclarecer que as práticas de bullying colidem frontalmente com os direitos fundamentais previstos no art. $5^{\circ}$ da Constituição Federal de 1988, dentre eles:

Art. $5^{\circ}$ Todos são iguais perante a lei, sem distinção de qualquer natureza, garantindo-se aos brasileiros e aos estrangeiros residentes no País a inviolabilidade do direito à vida, à liberdade, à igualdade, à segurança e à propriedade, nos termos seguintes: 
II - ninguém será obrigado a fazer ou deixar de fazer alguma coisa senão em virtude de lei;

III - ninguém será submetido a tortura nem a tratamento desumano ou degradante;

X - são invioláveis a intimidade, a vida privada, a honra e a imagem das pessoas, assegurado o direito a indenização pelo dano material ou moral decorrente de sua violação;

\section{(...)}

XLI - a lei punirá qualquer discriminação atentatória dos direitos e liberdades fundamentais.

Além da Constituição Federal, o Código Civil impõe ao responsável a obrigação de reparar o prejuízo causado a outrem (art. 186 e 927 CC/02) e o Código de Defesa do Consumidor estabelece que o fornecedor de serviços responde pelos defeitos na prestação dos serviços (art. 14, CDC).

Ademais, o Estatuto da Criança e do Adolescente (ECA) prevê medidas protetivas e socioeducativas a jovens que cometam atos infracionais. Para que os atos descritos no ECA sejam caracterizados como bullying, deve estar presente o critério da repetitividade das agressões.

Vale ressaltar que o bullying, em si, não é crime. Quando ele estiver associado com práticas que constituem crimes, tais como: lesão corporal, calúnia, injúria, difamação ou constrangimento ilegal, os pais ou responsáveis devem registrar o fato em uma delegacia de polícia. Nos casos mais graves, se a escola não informar o Conselho Tutelar, poderá ser responsabilizada por omissão (art. 245, ECA). 
Quando o bullying é praticado por menores de 18 anos, caberá ao Ministério Público (com atribuição na Vara da Infância e da Juventude) pleitear ao juiz competente a apuração do ato infracional. O juiz poderá, assim, aplicar as medidas socioeducativas previstas no $\mathrm{ECA}^{53}$.

O assunto começou tímido nos tribunais, mas, nos últimos três anos, rompeu os obstáculos iniciais, de modo que decisões coibindo o bullying começam a surgir, sinalizando que o Poder Judiciário não irá tolerar tais condutas, punindo, assim, os responsáveis ${ }^{54}$.

\subsection{A responsabilidade civil por fato de terceiro}

Especialmente no que se refere ao bullying escolar, objeto do presente trabalho, o tema da responsabilidade civil por fato de outrem adquire notória relevância. Afinal, essa espécie de bullying é protagonizada por crianças e adolescentes, dentro do ambiente escolar. Diante desse cenário, caso a vítima do bullying ingresse com ação judicial pleiteando a reparação civil pelos danos por ela suportados, é preciso saber quem deverá arcar com a indenização devida.

A responsabilidade civil é definida por Sílvio Rodrigues como a obrigação que pode incumbir uma pessoa a reparar o prejuízo causado à outra por fato próprio, ou por fato de pessoas ou coisas que dela dependam. ${ }^{55}$

A regra, em sede de responsabilidade civil, é que cada um responda por seus próprios atos, exclusivamente pelo que fez. É a chamada responsabilidade direta, por fato próprio, cuja justificativa está no próprio princípio informador da teoria da reparação.

\footnotetext{
${ }^{53}$ SILVA, Ana Beatriz Barbosa. Op. cit. p.139.

${ }^{54}$ CALHAU, Lélio Braga. Op. cit. p.14.

${ }^{55}$ RODRIGUES, Silvio. Direito Civil. 12a ed. São Paulo: Saraiva, 1989. v. 4. p.4.
} 
A lei, todavia, algumas vezes, faz emergir a responsabilidade do fato de outrem ou de terceiro, a quem o responsável está ligado, de algum modo, por um dever de guarda, vigilância ou cuidado.

Assim, excepcionalmente, nas hipóteses previstas no art. 932 do Código Civil, uma pessoa pode vir a responder por fato de outrem. Teremos, então, a responsabilidade indireta, ou responsabilidade pelo fato de outrem. Nos termos do art. 932 do Código Civil, os pais respondem pelos atos dos filhos menores que estiverem sob o seu poder e em sua companhia; o tutor e o curador, pelos pupilos e curatelados; o patrão por seus empregados etc.

Nesses casos, a lei responsabiliza as pessoas indicadas porque elas tinham um dever de guarda, vigilância ou cuidado em relação a certas pessoas e se omitiram no cumprimento desse dever. Portanto, sustenta o doutrinador Sérgio Cavalieri que, em última instância, estas pessoas não respondem por fato de outrem, mas pelo fato próprio da omissão ${ }^{56}$.

Nesse sentido, salienta o autor que, para que a responsabilidade desborde do autor material do dano, alcançando alguém que não concorreu diretamente para ele, é preciso que esse alguém esteja ligado por algum vínculo jurídico ao autor do ato ilícito, de sorte a resultar-lhe, daí, um dever de guarda, vigilância ou custódia ${ }^{57}$.

Desse modo, a noção de responsabilidade indireta tem como fundamento os casos em que a lei impõe a alguém a responsabilidade de reparar ato danoso praticado por outra pessoa, mas vinculado ao responsável de alguma forma.

Dessa forma, a responsabilidade por fato de outrem, ou indireta, constitui exceção à regra geral de responsabilidade por ato próprio e ocorre quando alguém responde pela atuação de pessoas dependentes suas, sejam

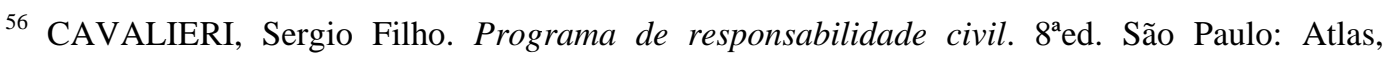
2009.p.25.

${ }^{57}$ Ibid. p.181. 
auxiliares, substitutos ou representantes, ou ainda pessoas de cuja vigilância se esteja incumbido, como filhos, alunos, pacientes e hóspedes (art.932, CC) ${ }^{58}$.

Nas palavras de Cavalieri, na realidade, a chamada responsabilidade por fato de outrem é responsabilidade por fato próprio omissivo, porquanto as pessoas que respondem a esse título terão sempre concorrido para o dano por falta de cuidado ou vigilância. Desse modo, não seria muito próprio falar em fato de outrem, uma vez que o ato do autor material do dano é apenas a causa imediata, sendo a omissão daquele que tem o dever de guarda ou vigilância a causa mediata, que nem por isso deixa de ser causa eficiente.

Em apertada síntese, a responsabilidade pelo fato de outrem constitui-se pela infração do dever de vigilância. Não se trata, em outras palavras, de responsabilidade por fato alheio, mas por fato próprio decorrente da violação do dever de vigilância. Por isso, alguns autores preferem falar em responsabilidade por infração dos deveres de vigilância, em lugar de responsabilidade pelo fato de outrem ${ }^{59}$.

Comentando o tema, Alvino Lima assevera que a responsabilidade do titular do poder familiar pelos danos ocasionados por seus filhos menores, sendo uma decorrência do exercício daquele poder, não constitui uma responsabilidade indireta. Incluiria-se, no entanto, entre os casos de responsabilidade pelo fato de terceiro, exclusivamente porque o ato material do dano é de autoria de outrem, isto é, do filho menor. Mas, tal responsabilidade seria direta, em virtude da violação dos deveres dos pais no exercício do poder familiar. Assim, a causa do dano estaria na violação

\footnotetext{
${ }^{58}$ BEGALLI, Paulo Antonio. Responsabilidade civil dos pais por atos dos filhos menores. Rio de Janeiro: Forense, 2005. p. 81.

${ }^{59}$ CAVALIERI, Sergio. Filho. Op. cit. p.182.
} 
dos deveres de vigilância ou de educação, por parte do titular do poder familiar, sendo o filho apenas o instrumento material do ato danoso. ${ }^{60}$

Em complemento, sustenta Paulo Antonio Begalli que a responsabilização por fato de outrem não derroga o princípio da personalidade da culpa, porque a pessoa declarada civilmente responsável é, ela própria, havida pela lei como tendo cometido o ato danoso, no mínimo, por negligência ou imprudência, uma vez que deixou de efetuar a regular guarda sobre o verdadeiro agente ${ }^{61}$.

Na vigência do Código Civil de 1916, travou-se forte controvérsia a respeito da natureza da responsabilidade indireta - se com culpa provada, em face do que dispunha o art.1523 (in verbis:Art. 1.523 - Excetuadas as do art. $1.521, \mathrm{~V}$, só serão responsáveis as pessoas enumeradas nesse e no art. 1.522, provando-se que elas concorreram para o dano por culpa, ou negligência de sua parte) ; se com culpa presumida ou, ainda, se objetiva. Prevaleceu o entendimento de que a noção de culpa presumida era suficiente para fundamentá-la, mas a presunção seria relativa, juris tantum, e não absoluta.

Tal presunção baseava-se, em primeiro lugar, num dado de experiência, segundo o qual boa parte dos atos ilícitos praticados pelos incapazes procederia de uma falta de vigilância adequada; em segundo lugar, na própria conveniência de estimular o cumprimento dos deveres que recaiam sobre aqueles a cuja guarda o incapaz esteja entregue; por último, na necessidade de acautelar o direito de indenização do lesado contra o risco da irresponsabilidade ou da insolvabilidade do autor direto da lesão.

Não obstante a controvérsia acima relatada, o art. 933 do Código Civil de 2002 acabou com qualquer discussão a respeito da natureza da responsabilidade indireta, ao dispor que as pessoas indicadas nos incisos I a

\footnotetext{
${ }^{60}$ LIMA, Alvino. A responsabilidade civil pelo fato de outrem. Rio de Janeiro: Forense, 1973. p. 34.

${ }^{61}$ BEGALLI, Paulo Antonio. Op. cit. p. 83.
} 
V do art. 932 responderão, ainda que não haja culpa de sua parte, pelos atos praticados pelos terceiros ali referidos.

Portanto, a responsabilidade por fato de outrem é agora objetiva e não mais com culpa presumida, o que evidencia a opção objetivista do atual Código ${ }^{62}$.

\subsubsection{A responsabilidade dos pais pelos atos dos filhos menores}

O tema da responsabilidade civil dos pais pelos atos dos filhos menores tende a assumir, na atualidade, uma importância crescente, devido a diversos fatores sociais, tais como a ausência, por razões profissionais, de ambos os pais do lar; o número crescente de crianças confiadas a terceiros; a independência cada vez mais precoce dos menores e a agressividade cada vez mais acentuada destes, os quais contribuem para a multiplicação dos danos causados por pessoas carecidas de vigilância ${ }^{63}$.

No que se refere ao bullying escolar, tendo em vista que os envolvidos são, na maior parte das vezes, menores de idade, é possível que os pais venham a ser chamados à responsabilização pelos danos causados por seus filhos menores, nos termos adiante expostos.

Consoante o disposto no inciso I do art. 932 do Código Civil, os pais são responsáveis pela reparação civil dos danos causados pelos filhos menores. O objetivo da norma, segundo Cavalieri, é aumentar a possibilidade de a vítima receber a indenização, já que o menor, ordinariamente, não tem patrimônio próprio suficiente para reparar o dano.

Conforme o autor, essa espécie de responsabilidade tem por fundamento o exercício do poder familiar, o qual impõe aos pais obrigações várias, entre as quais a de assistência material e moral (alimentos, educação,

\footnotetext{
${ }^{62}$ CAVALIERI, Sergio Filho. Op. cit. p 182-183.

${ }^{63}$ BEGALLI, Paulo Antonio. Op. Cit. p. 84.
} 
instrução) e de vigilância, sendo esta nada mais que um complemento da obra educativa. Nesse sentido, a justificativa da responsabilidade dos pais em relação aos atos dos filhos menores, que é objetiva, por força do disposto no art. 933 do Código Civil, como já esclarecido acima, é o dever objetivo de guarda e vigilância legalmente imposto a eles. Esse dever de guarda e vigilância é exigível daquele que tem autoridade sobre outrem e enquanto o tiver em sua companhia ${ }^{64}$.

Antes do Código Civil de 2002, os doutrinadores procuravam estabelecer certa distinção. No que se refere aos menores de 16 anos, a responsabilidade dos pais era exclusiva, direta, como autores do dano, em razão da ausência de discernimento dos filhos, não obstante a prova liberatória possível.

De outro lado, quando maior de 16 e menor de 21 anos, com notória visão da vida e discernimento preciso, advinha a responsabilidade solidária dos pais, equiparados que eram os filhos aos maiores.

O Código Civil de 2002 inovou no tocante à idade, estabelecendo a maioridade em 18 anos, sendo certo que, em qualquer hipótese, a responsabilidade dos pais perdurará, aplicando-se a todos os atos ilícitos, independentemente da imputabilidade ou não do menor, desde que presentes os requisitos legais. ${ }^{65}$

Assim, no sistema atual, os pais assumem, em regra, a responsabilidade pelos atos danosos de seus filhos menores, em razão de irregularidade na vigilância, ou deficiência na educação.

De fato, os pais, como decorrência do poder familiar exercido sobre os filhos menores, enfeixam em si inúmeros direitos e obrigações, cristalizando-se na expressão “poder-dever”, os quais devem ser cumpridos e exercidos regularmente, sob pena de responsabilização.

\footnotetext{
${ }^{64}$ CAVALIERI, Sergio Filho. Op. cit. p. 186.

${ }^{65}$ BEGALLI, Paulo Antonio. Op. cit. p. 3.
} 
Em primeiro plano, é imposta aos pais a obrigação precípua da criação e educação dos filhos, prestando-lhes assistência contínua, não só material, como também moral. Correlatamente, há o dever de vigilância, que envolve todos os atos dos filhos, resguardando-os da prática de atos lesivos aos seus semelhantes. Daí os deveres in educando e in vigilando, emanados do poder familiar, cujos eventuais desvios, notadamente na vigilância, acarretam a responsabilidade dos pais por atos nocivos praticados por seus filhos menores a outrem. ${ }^{66}$

Nesse sentido, percebe-se que a responsabilidade objetiva dos pais pelos atos dos filhos menores reside tanto no dever de vigilância imposto àqueles em relação a estes, como no dever de assistência material e moral que lhes é exigido, donde se extrai o dever de direção da conduta dos filhos, consoante o disposto no art. 22 do Estatuto da Criança e do Adolescente (ECA), que atribui aos pais o dever de sustento, guarda e educação dos filhos menores.

Diante desse cenário, compreende-se que o munus do poder familiar, além de enfeixar diversas prerrogativas, traz em seu bojo um conjunto de encargos, dentre os quais o de responder pelos atos dos filhos que venham a causar danos a terceiros. Em outras palavras, o poder familiar, por si só, não é fonte de responsabilidade civil, mas a inobservância de seus encargos, por ação ou omissão, pode sê-la.

O Código Civil, no art. 1.634, enumera os direitos e deveres dos pais em relação aos filhos. Desse modo, a responsabilidade dos pais se relaciona intimamente com o exercício do poder familiar e deve ser julgada em função desse dever, que impõe ao seu titular obrigações de conteúdo especial, notadamente no tocante à vigilância.

A culpa in vigilando, que era presumida na vigência do Código Civil de 1916, supunha a falta de diligência dos sujeitos responsáveis para evitar

\footnotetext{
${ }^{66}$ Ibid. p. 88.
} 
que as pessoas que tinham sob o seu cuidado ou dependência cometessem atos que pudessem causar danos a terceiros ou a si próprios. Assim, o poder-dever de vigilância dos pais seria mais dever do que poder, tendo por fim proteger o menor dos perigos e evitar que ele prejudicasse terceiros.

Desse modo, a culpa in vigilando exprimiria um juízo de censura pela omissão de um dever de vigilância condicionado pela adoção de cautelas adequadas à guarda do menor ${ }^{67}$.

Como já esclarecido acima, o Código Civil de 2002 não mais pauta a responsabilidade dos pais pelos atos dos filhos menores na presunção de culpa in vigilando, sendo esta responsabilidade, atualmente, objetiva, isto é, independente de culpa, nos termos do art.933 do CC/02.

No que se refere ao dever de educação imposto aos titulares do poder familiar, observa Jeovanna Viana que o objetivo da educação reside na preparação gradual dos filhos - sendo ela física, moral e intelectual - para que eles, aproveitando da sua crescente faculdade, possam reger com autonomia e independência a sua pessoa e administrar os seus bens, estando, assim, preparados para viver e conviver em uma sociedade civilizada, sabendo respeitar os direitos dos demais ${ }^{68}$.

José de Aguiar Dias, citando Sourdat, revela que o poder familiar inspira a responsabilidade civil dos pais, porque dá e eles o direito e o dever de velar constantemente pelos filhos, enquanto estes ainda são incapazes de dirigir as suas ações, e de prevenir-lhes as falhas, seja pela vigilância atual, seja principalmente pela educação intelectual e moral que estão incumbidos de dar ao menor.

Assim, tendo em vista os deveres impostos aos pais em relação aos seus filhos, eles podem ser agrupados em deveres de assistência - que não é só material, traduzida na prestação de alimentos e satisfação de

\footnotetext{
67 ALVES, Jeovanna Malena Viana. Responsabilidade civil dos pais pelos actos dos filhos menores. Rio de Janeiro: Renovar, 2004. p. 45.

${ }^{68}$ Ibid. p. 52.
} 
necessidades econômicas; mas também moral, compreendendo a instrução e educação - e nos deveres de vigilância. Quanto à vigilância, aduz José de Aguiar Dias que ela é o complemento da obra educativa ${ }^{69}$.

Desse modo, a responsabilidade dos pais, consequência da obrigação de vigilância de seus filhos menores, está incluída no conteúdo do poder familiar, estando previsto este poder-dever dos pais como um meio de proteger os seus filhos. Assim, ao direito de guarda do filho menor e de lhe impor a vida em comum, correspondem os deveres de vigilância, de educação e de direção de sua conduta, impondo-lhe a correção necessária.

Portanto, tais deveres, inclusos no poder familiar, não devem ser descumpridos, principalmente porque de sua transgressão podem surgir violações dos direitos de terceiros, ocasionando-lhes danos, o que gerará a responsabilização dos progenitores pelos ilícitos praticados pelos filhos menores $^{70}$.

Segundo o art. 928 do Código Civil, o incapaz responde pelos prejuízos que causar se as pessoas por ele responsáveis não tiverem obrigação de fazê-lo ou não dispuserem de meios suficientes. Portanto, busca-se, em primeiro lugar, o patrimônio dos responsáveis e, depois, a pretensão é dirigida contra o próprio incapaz.

Numa interpretação conjunta dos artigos 928 e 932, I, do Código Civil, verifica-se que, num primeiro momento, os pais são responsáveis pela reparação civil dos prejuízos causados pelos filhos menores (art. 932, I, CC) e, caso não possuam patrimônio, remanesce a possibilidade de responsabilização do próprio menor, se este possuir respaldo patrimonial e desde que este fato não lance a ele e as pessoas que dele dependem no estado de penúria. Neste caso, fica reservado ao juiz o poder de analisar se a

\footnotetext{
${ }^{69}$ DIAS, José de Aguiar. Da responsabilidade civil. $11^{\mathrm{a}}$ edição. Rio de Janeiro: Renovar, 2009. p. 152.

${ }^{70}$ ALVES, Jeovanna Malena Viana. Op.cit. p. 109-110.
} 
responsabilização é cabível, bem como o seu respectivo montante. Em suma, os pais são os responsáveis e, subsidiariamente, os próprios menores.

\subsubsection{Pressupostos da responsabilidade dos pais}

A grande maioria da doutrina pátria elenca como pressupostos para a responsabilização paterna pelos atos dos filhos menores a menoridade, a relação de paternidade, a convivência (ou coabitação) e o ato ilícito praticado pelo menor. Dentre esses requisitos, merecem atenção mais detalhada os seguintes:

- Filhos menores que estiverem sob sua autoridade e em sua companhia

Nos termos do art. 932 do Código Civil, os pais só são responsáveis pelos filhos menores que estiverem sob sua autoridade e em sua companhia. De acordo com Cavalieri, o fundamento da responsabilidade indireta é o dever objetivo de guarda e vigilância legalmente imposto aos pais, sendo o referido dever exigível daquele que tem autoridade sobre outrem e enquanto o tiver em sua companhia.

Segundo o autor, ter o filho sob sua autoridade e em sua companhia significa tê-lo sob o mesmo teto, de modo a possibilitar o poder de direção dos pais sobre o menor e a sua eficiente vigilância ${ }^{71}$.

Corroborando o acima exposto, sustenta Paulo Antonio Begalli que viver na companhia dos pais supõe que o menor se abrigue no mesmo teto, que permaneça na casa da família, possibilitando a vigilância dos pais.

Portanto, ainda que haja relação de poder familiar estabelecida, se o filho estiver em companhia de outrem (por exemplo, internado em colégio ou confiado à guarda de outro cônjuge), a responsabilidade recairá sobre

\footnotetext{
${ }^{71}$ CAVALIERI, Sergio Filho. Op. cit. p. 186.
} 
aquele a quem incumbir o dever de vigilância. Significa dizer que não é suficiente que o menor esteja sob o poder familiar, é preciso também que viva em companhia dos pais para que haja a responsabilidade paterna.

Nesse sentido, se o filho, justificadamente, não estiver na companhia dos pais e sob sua guarda, a responsabilidade destes não se caracterizará. Mas, se o menor, por culpa do pai, se encontra alhures na guarda de terceiros e causa dano a outrem, o genitor terá que indenizar ${ }^{72}$.

Conforme Cavalieri, os pais só poderão exonerar-se da responsabilidade objetiva em relação aos atos dos filhos menores quando eles perderem, jurídica e justificadamente, o poder de direção sobre o filho menor, cabendo-lhes o ônus dessa prova. Assim, no caso de os pais estarem separados, um deles ausente ou interdito, a responsabilidade será daquele (pai ou mãe) que tem o filho sob sua posse e guarda, exercendo sobre ele o poder de direção.

Desse modo, se, de maneira contínua e fora do domicílio paterno, o menor é confiado à guarda dos avós, de educador, de estabelecimento de ensino, ou trabalha para outrem, sustenta Cavalieri que a estes caberá a responsabilidade durante o período em que exercerem o poder de direção sobre o menor, e assim por diante.

Percebe-se, então, que a responsabilidade dos pais pode ser intermitente, cessando e restaurando-se conforme a delegação de vigilância, efetiva e a título de substituição. De acordo com Cavalieri, nem toda delegação de vigilância transfere a responsabilidade dos pais; somente aquela que tem caráter de substituição, permanente ou duradoura, e feita juridicamente a quem tem condições de exercer responsavelmente o poder de direção sobre o menor. O simples afastamento do filho da casa paterna, por si só, não elide a responsabilidade dos pais ${ }^{73}$.

\footnotetext{
${ }^{72}$ BEGALLI, Paulo Antonio. Op. cit. p.123.

${ }^{73}$ CAVALIERI, Sergio Filho. Op. cit. p.186-187.
} 
Em síntese, a vigilância do menor é inerente ao dever de guarda imposto ao guardião em relação ao filho. Cabe ao guardião zelar com atenção máxima para que o menor não se envolva em perigos e também não moleste terceiros. Se o fizer, por culpa ou dolo, é de se entender que falhou o guardião, sendo o dano causado suficiente para demonstrá-lo.

Dessa forma, as condições legais para a responsabilização dos pais são duas: o exercício do poder familiar e o exercício da guarda. Nas palavras de Begalli, o elemento de ligação é a guarda: se a guarda é indevida, ou quem devia guardar o menor não o guarda, ligado fica quem o devia guardar e não o guardou, ou confiou, ou aquiesceu na guarda de outrem $^{74}$. Portanto, aduz o autor que o fundamento do dever de indenizar é a guarda e não o poder familiar. ${ }^{75}$

\section{- Ato ilícito praticado pelo menor}

Como já demonstrado anteriormente, não mais se pauta a responsabilidade dos pais na presunção relativa de culpa in vigilando, devendo os mesmos indenizar a vítima simplesmente porque são pais do menor causador do dano e o tinham sob sua autoridade e em sua companhia. Entretanto, se, ao menos em tese, o fato não puder ser imputado ao agente a título de culpa, os responsáveis não terão que indenizar.

Nesse sentido, esclarece Cavalieri que objetiva é a responsabilidade dos pais e não a das pessoas pelas quais eles são responsáveis. Assim, em qualquer das hipóteses elencadas pelo art. 932, será necessária a prova de uma situação que, em tese, configure a culpa do filho menor ${ }^{76}$.

No mesmo sentido, ensina Carlos Roberto Gonçalves. Segundo o autor, está sujeito à reparação do dano, por exemplo, o pai que permite ao filho menor de 18 anos sair de automóvel. Se o filho, culposamente, provoca acidente de trânsito, o lesado tem direito de acionar o pai para

\footnotetext{
${ }^{74}$ BEGALLI, Paulo Antonio. Op. cit. p. 128-129.

${ }^{75}$ Ibid. p. 166.

${ }^{76}$ CAVALIERI, Sergio Filho. Op.cit. p. 183-184.
} 
obter indenização. Da mesma forma, responde pelo ressarcimento do dano causado pelo filho o pai que não o educa bem ou não exerce vigilância sobre ele, possibilitando-lhe a prática de algum delito, como incêndio, o furto, a lesão corporal e outros. Em todos esses casos, comprovado o ato ilícito do menor, dele decorre, por via de consequiência e independentemente de culpa do pai, a responsabilidade deste ${ }^{77}$. (grifos nossos)

Diante do exposto, constata-se que, no regime de responsabilidade civil positivado pelo Código Civil de 2002, os pais respondem objetivamente pelos atos dos filhos até os 18 anos. A vítima não necessita provar que o fato ocorreu por culpa in vigilando dos pais, bastando a prova do dano (art. 933, Código Civil) e que ele foi causado por fato culposo do filho. Essa prova é necessária, pois objetiva é apenas a responsabilidade dos pais e não a do filho. Sem culpa do filho, não haverá que se falar em indenização. Provada a culpa do filho, exsurge a responsabilidade dos pais, que só poderão exonerar-se do dever de indenizar demonstrando in concreto que não mais tinham o poder de direção sobre o menor e, portanto, o correspondente dever de vigilância ${ }^{78}$.

\subsubsection{A responsabilidade dos estabelecimentos de ensino pelos atos dos educandos}

Além da análise da responsabilidade dos pais pelos atos dos filhos menores, o estudo da responsabilidade pelos atos de bullying escolar praticados por menores, quando fontes de danos materiais e morais, necessita debruçar-se sobre o tema da responsabilidade dos estabelecimentos de ensino pelos atos dos educandos, tendo em vista que essa espécie de bullying acontece dentro do ambiente escolar.

\footnotetext{
${ }^{77}$ GONÇALVES, Carlos Roberto. Responsabilidade Civil. $8^{\mathrm{a} e d .}$ Rio de Janeiro: Saraiva, 2009. p. 133.

${ }^{78}$ CAVALIERI, Sergio Filho. Op. cit. p. 187-188.
} 
O art. 932, IV, do Código Civil, determina a responsabilidade dos estabelecimentos de ensino pelos atos ilícitos praticados por seus educandos. Ademais, o art. 14 do Código de Defesa do Consumidor estabelece responsabilidade objetiva para todos os fornecedores de serviços em relação aos danos causados aos seus hóspedes, educandos etc. que tenham por causa o defeito do serviço - fato do serviço - só lhes sendo possível afastar o dever de indenizar nas hipóteses previstas no $\S 3^{\circ}$ do mesmo dispositivo legal. Essa responsabilidade tem por fundamento o dever do fornecedor de prestar serviços seguros, ou seja, sem defeito. Tratase de responsabilidade direta, fundada no fato do serviço.

A jurisprudência dos Tribunais, inclusive do STJ, vem se firmando no sentido de enquadrar no Código de Defesa do Consumidor a responsabilidade dos hotéis, educandários e outros estabelecimentos fornecedores de serviços pelos danos causados aos seus hóspedes, educandos e demais consumidores, conforme o ramo do serviço prestado pelo estabelecimento fornecedor.

No que se refere propriamente à responsabilidade dos estabelecimentos de ensino, ao receberem o estudante menor, confiados à instituição da rede oficial ou da rede particular para as atividades curriculares, de recreação, aprendizado e formação escolar, as entidades de ensino ficam investidas no dever de guarda e preservação da integridade física do aluno, com a obrigação de empregar a mais diligente vigilância, com o fim de prevenir e evitar qualquer ofensa ou dano aos seus pupilos que possam resultar do convívio escolar.

Dessa forma, a escola responderá no plano reparatório se, durante a permanência no interior do estabelecimento, o aluno sofrer violência física por inconsiderada atitude de colega, de professor ou de terceiros, ou, ainda, qualquer atitude comissiva ou omissiva da direção do estabelecimento, se lhe sobrevierem lesões que exijam a reparação. 
No que pertine à escola pública, a responsabilidade se filia ao princípio consagrado no art. 37 , par. $6^{\circ}$, da Constituição Federal, configurando-se pela simples falha na garantia da incolumidade, independente de culpa específica de qualquer servidor. ${ }^{79}$

Frise-se que a responsabilidade do estabelecimento de ensino pelos danos causados aos seus educandos é restrita ao período em que estiverem sob a vigilância dos mesmos, compreendendo apenas o que ocorre no interior do estabelecimento, ou em seus domínios. Nesse sentido, afirma Cavalieri que os pais não podem ser responsabilizados por atos dos filhos menores enquanto estes se encontram sob a guarda do colégio ${ }^{80}$.

Ademais, sustenta Caio Mário que, uma vez que o estabelecimento tem o dever de vigilância dos seus educandos, responderá pelos atos por eles praticados, não cabendo ação regressiva contra os pais, pois, confiado o menor ao estabelecimento, assume este a sua vigilância ${ }^{81}$.

No que se refere ao bullying escolar, consoante jurisprudência majoritária, os danos ocorridos a menores dentro das escolas são responsabilidade destas, em razão do seu dever de vigilância dos estudantes, equiparando-se os danos a defeito do serviço.

Entretanto, percebe-se na jurisprudência pátria a tendência de entender-se que a responsabilidade da escola só restará configurada nos casos em que ela não tenha tomado as medidas adequadas para solucionar o problema.

Dessa forma, muito embora o dever de vigilância dos menores seja atribuído à instituição de ensino enquanto eles estiverem dentro do estabelecimento escolar, os Tribunais têm entendido por isentar a instituição e responsabilizar exclusivamente os pais quando ficar

\footnotetext{
${ }^{79}$ STOCO, Rui. Responsabilidade Civil e sua interpretação Jurisprudencial. $3^{\mathrm{a}}$ ed. Rio de Janeiro: Ed. Revista dos Tribunais, 1997. p. 431

${ }^{80}$ CAVALIERI, Sergio Filho. Op. cit. p. 197-198.

${ }^{81}$ PEREIRA, Caio Mário da Silva. Responsabilidade civil. $9^{\mathrm{a}}$ ed. Rio de Janeiro: Forense, 1998. p. 98-99.
} 
comprovado que a escola tomou todas as atitudes consideradas pedagogicamente necessárias para solucionar a situação de bullying, enquanto os pais do agressor ficaram inertes e nada fizeram para tentar cooperar no combate à violência escolar protagonizada por seus descendentes, como se verá adiante.

\subsection{A responsabilidade das instituições de ensino no bullying escolar e a jurisprudência}

Como já afirmado anteriormente, haverá responsabilidade da instituição escolar pelos atos de bullying praticados dentro do estabelecimento, em razão do seu dever de vigilância dos estudantes, equiparando-se os danos a defeito do serviço. Ademais, a responsabilização imputada às escolas é objetiva, sejam elas públicas (art.37, CF), ou privadas (art.14, CDC).

No que se refere aos atos praticados fora do estabelecimento de ensino, salienta o Promotor Lélio Braga Calhau que a situação demandará uma análise da prova dos autos, que deverá ser conclusiva no sentido de atestar tratar-se de uma extensão de atos de bullying praticados também dentro da escola.

Nesse sentido, aduz o autor que pode haver atos de bullying praticados sem violência dentro da escola, porém com violência fora dela (ex: saída do colégio), havendo uma conexão dos fatos que, em tese, configurariam uma mesma ocorrência do processo (dinâmico) do bullying, devendo, na opinião de Lélio, a instituição ser responsabilizada também nesses $\operatorname{casos}^{82}$.

O Tribunal de Justiça do Rio de Janeiro, em um recurso de apelação cível julgado no ano de 2010, isentou a instituição de ensino da condenação

\footnotetext{
${ }^{82}$ CALHAU, Lélio Braga. Op. cit. p. 41.
} 
ao pagamento de indenização por danos morais em razão da prática de bullying, em função da ausência de comprovação do cometimento de agressões no interior do estabelecimento escolar ${ }^{83}$.

Para o TJRJ, no caso, embora tenha restado incontroverso que diversos alunos irrigaram injúrias contra a autora, via internet, configurando-se o chamado cyberbullying, não há como imputar à escola a responsabilidade pelos fatos ocorridos, tendo em vista que as ofensas propagaram-se em ambiente alheio à esfera de guarda e vigilância da instituição de ensino, limitada esta às dependências do estabelecimento escolar. (grifos nossos)

Ademais, de acordo com o Tribunal, as provas dos autos demonstraram que o estabelecimento de ensino adotou as providências adequadas após a ciência dos desentendimentos entre as alunas envolvidas no bullying escolar, realizando entrevista com a autora da ação, a fim de apurar os fatos alegados; comunicando os responsáveis legais de ambas as estudantes; procedendo à oitiva dos alunos envolvidos no incidente e, posteriormente, transferindo a autora para classe diversa, comprovando-se, dessa forma, a observância do dever de guarda e vigilância imposto aos educadores em geral.

Nesse sentido, observa-se que não haverá responsabilidade da instituição de ensino quando as ofensas caracterizadoras do bullying escolar ocorrerem fora do âmbito de guarda e vigilância da escola, isto é, fora das dependências do estabelecimento escolar, pois, nesses casos, torna-se impossível à escola adotar qualquer tipo de providência, tendo em vista que os educadores não são onipresentes ou oniscientes.

Assim, a escola só pode ser chamada à responsabilidade objetiva pela falha na prestação dos serviços educacionais quando o bullying é

\footnotetext{
${ }^{83}$ TJRJ, Apelação Cível no 0015239-71.2007.8.19.0203, Rel. Desembargador Carlos Eduardo da Fonseca Passos. Rio de Janeiro, 28 jul. 2010.
} 
praticado em suas dependências, ou, como sustentado pelo Promotor Lélio Braga, quando houver uma conexão dos fatos ocorridos dentro e fora da instituição de ensino, configurando uma mesma ocorrência do processo dinâmico do bullying. A análise deve ser feita caso a caso, através da observância das provas dos autos, a fim de apurar a responsabilidade, ou não, da instituição.

No que se refere ao cyberbullying, ou bullying virtual, objeto do julgado acima comentado, torna-se ainda mais difícil a imputação da responsabilidade a alguém pelos danos suportados pelas vítimas, tendo em vista que as agressões se propagam através dos meios eletrônicos, longe, portanto, da esfera escolar.

Segundo Rodrigo Nejm, psicólogo e diretor de prevenção da SaferNet Brasil, ONG voltada ao combate dos crimes praticados na internet:

"No mundo real, a agressão tem começo, meio e fim. Na internet, ela não acaba, fica aquele fantasma" ${ }^{84}$.

O resultado preliminar de uma enquete sobre segurança na internet realizada no site da ONG assusta: $46 \%$ dos 510 adolescentes e crianças que responderam ao questionário afirmam que foram vítimas de agressões na internet ao menos uma vez; 34,8\% dizem que foram agredidos mais de duas vezes. Dos participantes, $31 \%$ são do Estado de São Paulo, onde há o maior número de relatos, segundo a SaferNet.

De acordo com o Promotor Lélio Braga, o Poder Judiciário tem se mostrado atento ao tema do cyberbullying e tem autorizado, desde que haja a apresentação de provas iniciais adequadas (ex: impressão das páginas da internet com as agressões), a quebra do sigilo de dados dos envolvidos, com

\footnotetext{
${ }^{84}$ Disponível em <http://www.safernet.org.br/site>. Acesso em 05 maio 2011.
} 
o intuito de identificar a autoria dessas agressões. Isso é possível porque os agressores deixam um importante rastro na internet, que é o número de IP (internet protocol), através do qual é possível identificar de qual conexão à internet partiram aquelas agressões.

Orienta Lélio que, em caso de ocorrência de cyberbullying, é necessário salvar a página da internet imediatamente, através da tecla "print screen", pois, ao descobrirem que a polícia foi acionada, os agressores tendem a apagar os vestígios da agressão na internet ${ }^{85}$.

Em um julgado do ano de 2007, o Tribunal de Justiça do Estado de Minas Gerais confirmou uma condenação no valor de R\$ 3.500,00 num caso de cyberbullying, onde o instrumento utilizado foi o Orkut. ${ }^{86}$

Para o TJMG, o Orkut é um serviço fornecido gratuitamente, com o objetivo de incentivar seus usuários a criar novas amizades e manter relacionamentos, havendo milhões de usuários que criam perfis para se relacionar com os demais usuários cadastrados, que ali compartilham e buscam informações, sendo tais informações de livre acesso, de modo que não apenas os participantes da comunidade podem visualizar o seu conteúdo. Assim, se o ofendido tem sua imagem exposta na rede, através da publicação de foto e texto criticando atitudes e características suas, com caráter pejorativo e difamatório, o criador e controlador das atividades do grupo deve responder pelos danos morais daí defluentes.

Ainda, salienta o desembargador relator que o autor do cyberbullying, certamente, não esperava que a sua conduta redundasse em uma ação de indenização por danos morais, já que escudado atrás de um pretenso anonimato, como é usual dentre os usuários da Internet. No caso em tela, vazado o inconformismo da vítima, o autor da agressão deletou o grupo em apreço, a fim de desfazer-se das provas de ocorrência do ilícito.

\footnotetext{
${ }^{85}$ CALHAU, Lélio Braga. Op. cit. p. 59-60.

${ }^{86}$ TJMG, Apelação Cível n ${ }^{\circ}$ 1.0024.05.890294-1/001(1), Rel. Desembargador Tarcísio Martins Costa. Minas Gerais, 10 abril 2007.
} 
Desse modo, o julgado em questão revela a dificuldade em responsabilizar civilmente os autores de atos de cyberbullying, pois, além da dificuldade na sua identificação, é muito comum que eles apaguem o conteúdo das ofensas do mundo virtual assim que descobrem que estão sendo investigados.

Voltando ao tema da responsabilidade legal das instituições no bullying escolar, embora o TJRJ tenha isentado a escola no caso de cyberbullying antes comentado, uma vez que as agressões não tinham ocorrido dentro do estabelecimento escolar, é pacífico na jurisprudência o posicionamento de que as agressões caracterizadoras de bullying ocorridas dentro da instituição são de responsabilidade desta, salvo se ficar comprovado que a escola tomou todas as medidas consideradas pedagogicamente essenciais, caso em que a responsabilidade poderá recair nos pais do menor, se estes houverem sido desidiosos, como se verá adiante.

Corroborando o acima exposto, o Tribunal de Justiça do Distrito Federal e Territórios (TJDFT), em um recurso de apelação cível, julgado no ano de 2008, condenou uma escola a indenizar a família de uma vítima de bullying, arbitrando a quantia de $\mathrm{R} \$ 3.000,00$, a título de danos morais ${ }^{87}$.

Para o TJDFT, no caso, restou demonstrado nos autos que a vítima sofreu agressões físicas e verbais de alguns colegas de turma que iam muito além de pequenos atritos entre crianças daquela idade, no interior do estabelecimento réu, durante todo o ano letivo de 2005.

Aduz o desembargador relator que é certo que tais agressões, por si só, configuram dano moral, cuja responsabilidade de indenização é do colégio, em razão de sua responsabilidade objetiva. Com efeito, o colégio réu tomou algumas medidas na tentativa de contornar a situação, contudo,

\footnotetext{
${ }^{87}$ TJDFT. Apelação Cível $n^{\circ}$ 20060310083312. Rel. Desembargador Waldir Leôncio Júnior. Brasília, 09 jul. 2008.
} 
tais providências foram inócuas para solucionar o problema, tendo em vista que as agressões se perpetuaram pelo ano letivo.

Ainda, assevera o relator que, provavelmente, o estabelecimento de ensino não atentou para o papel da escola como instrumento de inclusão social, sobretudo no caso de crianças tidas como "diferentes". Nesse ponto, registrou o magistrado que o ingresso no mundo adulto requer a apropriação de conhecimentos socialmente produzidos.

Segundo ele, a interiorização de tais conhecimentos e experiências vividas se processa, primeiro, no interior da família e do grupo em que este indivíduo se insere e, depois, em instituições como a escola. No dizer de Helder Baruffi, "neste processo de socialização ou de inserção do indivíduo na sociedade, a educação tem papel estratégico, principalmente na construção da cidadania."

O tribunal aplicou o Código de Defesa do Consumidor ao caso, tendo em vista que o fornecedor de serviços responde, independentemente da existência de culpa, pela reparação dos danos causados aos consumidores por defeitos relativos à prestação dos serviços.

No julgado ora em debate, a vítima produziu prova do dano em sua saúde e do nexo de causalidade (agressões caracterizadoras de bullying). O colégio, segundo o julgado, tomou medidas que não se mostraram efetivas para impedir o bullying, daí a sua responsabilidade.

Ademais, é de se destacar que o desembargador reconhece a responsabilidade concorrente da célula mater e da instituição de ensino na tarefa de contribuir para a formação dos jovens, o que reforça a tese, ora sustentada, da corresponsabilidade entre escola e pais no combate ao bullying escolar. 
Recentemente, neste ano de 2011, o Tribunal de Justiça do Rio de Janeiro condenou uma escola a pagar indenização por danos morais no valor de $\mathrm{R} \$ 35.000,00$ (trinta e cinco mil reais) à família de uma ex-aluna ${ }^{88}$.

A estudante, representada por seus pais, entrou com ação contra a escola relatando que, desde o início de 2003, vinha sofrendo agressões físicas e verbais por parte de colegas de classe.

$\mathrm{Na}$ época, a menor tinha apenas sete anos de idade e foi espetada na cabeça por um lápis, arrastada, sofreu arranhões, além de socos, chutes, gritos no ouvido, palavrões e xingamentos. Em virtude desses acontecimentos, configurados como bullying, a criança acabou adquirindo fobia de ir à escola, passou a ter insônia, terror noturno e sintomas psicossomáticos, como enxaqueca e dores abdominais, tendo que se submeter a tratamento com antidepressivos e, no fim do ano letivo, mudou de escola.

A entidade de ensino defendeu-se alegando ter tomado todas as medidas pedagógicas merecidas pelo caso, porém não entendeu ser conveniente o afastamento dos alunos da escola. Documentos comprovaram reclamações formuladas não só pelos pais da menina autora, como de outros alunos, que também sofriam bullying.

Para a $13^{\mathrm{a}}$ Câmara Cível do Tribunal de Justiça do Rio, o dano moral ficou configurado e a responsabilidade é da escola, pois, na ausência dos pais, a mesma detém o dever de manutenção da integridade física e psíquica de seus alunos, sendo certo que a responsabilidade é objetiva, pois se trata de falha na prestação do serviço educacional, configurada a relação de consumo, bastando, apenas, a comprovação do dano e do nexo causal.

\footnotetext{
${ }^{88}$ TJRJ. Apelação Cível $\mathrm{n}^{\circ}$ 0003372-37.2005.8.19.0208. Rel. Desembargador Ademir Paulo Pimentel. Rio de Janeiro, 02 fev. 2011.
} 
Também neste julgado, observamos que a orientação dos Tribunais é no sentido de averiguar, em cada caso, a conduta de todos os envolvidos na situação de bullying configurada, através da análise da prova dos autos, para, então, imputar a responsabilidade a alguém.

De fato, em ambos os episódios acima narrados, restou comprovada a insuficiência da atuação da instituição escolar, que se limitou a tomar providências inócuas, subestimando a gravidade do problema enfrentado pelas vítimas do bullying, o que contribuiu para agravar, ainda mais, a situação de sofrimento por elas vivenciada.

Ademais, constata-se que as escolas buscaram descaracterizar a ocorrência do bullying, alegando tratar-se de exagero e cuidado excessivo por parte dos pais "neuróticos", com o fim de verem afastada a sua responsabilidade enquanto prestadoras de serviço educacional, regidas pelo Código de Defesa do Consumidor, no caso de instituições de natureza privada.

Entretanto, os relatores, após realizarem uma análise acurada das provas dos autos, entenderam que, muito embora as instituições de ensino tenham tentado "colocar panos quentes" na situação e menosprezar o sofrimento das vítimas, o bullying escolar restou comprovado, deixando sequelas graves naqueles que foram vítimas, razão pela qual ambos os colégios foram condenados ao pagamento de indenização por danos morais, eis que estavam presentes o dano (sequelas advindas do bullying sofrido, como os traumas psicológicos, o tratamento com psicoterapeuta e o uso de medicamentos controlados relatados nos autos) e o nexo causal (tais sequelas advieram do bullying sofrido dentro das instituições de ensino).

Ainda, há que se observar que, no caso do julgado do Tribunal de Justiça do Rio de Janeiro, a menor ingressou em juízo representada por seu pai e sua mãe, sendo certo que o valor da indenização de $\mathrm{R} \$ 35.000,00$ representa o montante total devido pela instituição, dividindo-se o valor em 
$\mathrm{R} \$ 15.000,00$ para a menor e $\mathrm{R} \$ 10.000,00$ para o pai e para mãe, cada um, pois, consoante o posicionamento do Juízo, é evidente que o sofrimento vivenciado pela menor extrapolou seu próprio âmbito, atingindo também seus pais, razão pela qual estes se mostraram merecedores de indenizações próprias, a título de danos morais.

Assim, os efeitos do ato ilícito repercutiram não apenas diretamente sobre a vítima, mas também sobre pessoa próxima, titular do direito atingido pelo dano de relação. Trata-se de hipótese de danos morais reflexos, ou seja, embora o ato tenha sido praticado diretamente contra determinada pessoa, seus efeitos acabaram por atingir, indiretamente, a integridade moral de terceiros. É o chamado dano por ricochete: há ofensa direta a um bem jurídico e ofensa indireta a bem jurídico de terceiro.

Sérgio Cavalieri leciona a respeito do tema que os efeitos do ato ilícito podem repercutir não apenas diretamente sobre a vítima, mas também sobre pessoa intercalar, titular de relação jurídica que é afetada pelo dano não na sua substância, mas na sua consistência prática. Prossegue afirmando que somente o dano reflexo certo e que tenha sido consequência direta e imediata da conduta ilícita pode ser objeto de reparação, ficando afastado aquele que se coloca como consequência remota, ou mera perda de uma chance ${ }^{89}$.

Finalmente, no que se refere à responsabilização objetiva das instituições escolares públicas, o Tribunal de Justiça do Rio Grande do Sul, em um julgado de 2007, condenou o Município a pagar indenização por danos morais no valor de $\mathrm{R} \$$ 60.000,00 (sessenta mil reais) à vítima, que teve perda da visão em um dos olhos em razão do arremesso de uma tesoura por colega de classe ${ }^{90}$.

\footnotetext{
${ }^{89}$ CAVALIERI, Sergio Filho. Op. cit. p. 115-116

${ }^{90}$ TJRS. Apelação Reexame necessário $n^{\circ}$ 70019324268. Rel. Desembargador Odone Sanguiné. Rio Grande do Sul, 04 dez. 2007.
} 
No caso, um aluno da instituição de ensino municipal arremessou, dentro da sala de aula, uma tesoura contra outro, causando-lhe substancial perda da visão em um dos olhos. Segundo o TJRS, o sistema jurídico brasileiro adota a responsabilidade patrimonial objetiva do Estado sob a forma da Teoria do Risco Administrativo, com base no art. 37, § $6^{\circ}$, da Constituição Federal. Nesse sentido, para que incida a responsabilidade objetiva, há necessidade de que o dano causado a terceiros seja provocado por agentes estatais nessa qualidade.

De acordo o relator, a mãe da vítima já havia alertado a escola sobre a violência existente dentro da instituição de ensino, postulando a adoção de providências para resguardar a incolumidade dos alunos. Ademais, esclarece o julgado que a responsável já vinha questionando anteriormente a escola sobre a agressividade dirigida pelo bully contra seu filho na hora do recreio, no horário de educação física e na sala de aula. Entretanto, a escola se mostrou indiferente aos apelos da genitora, informando-a que se tratava de meros acidentes.

Assim, de acordo com o Tribunal, trata-se de hipótese de responsabilidade por fato próprio omissivo, uma vez que a escola municipal concorreu para o dano por violação do dever de vigilância - que é tanto mais forte quanto maior for a falta de discernimento do incapaz - no caso, um menino com apenas oito anos de idade, cuja guarda e vigilância estava sob responsabilidade do educandário. Além disso, esclarece o TJRS que a responsabilidade das escolas estende-se durante todo o tempo em que o menor se acha nela, inclusive nos recreios e excursões.

Nesse sentido, o ente público demandado não teria se desincumbido de seu ônus probatório, permanecendo responsável por indenizar os danos sofridos pelo menor, não se podendo falar em culpa exclusiva ou concorrente da vítima, tendo em vista que o menor agressor também estava sob os cuidados e vigilância do estabelecimento de ensino. 
Desse modo, percebe-se que se tratava de situação de bullying, embora o julgado não tenha denominado dessa forma, uma vez que restou comprovado que a vítima foi perseguida, durante todo o ano letivo, pelo menor agressor, já tendo sua mãe, inclusive, comunicado o caso à escola, a qual, no entanto, optou por não tomar nenhuma atitude.

Mais uma vez, constata-se que a responsabilidade objetiva da escola pelos danos materiais e morais suportados por seus alunos em razão de bullying escolar subsistirá sempre que restar caracterizado que a instituição não tomou as medidas julgadas pedagogicamente essenciais para solucionar o problema, adotando uma postura negligente em relação ao dever de vigilância que lhes é legalmente imposto, seja ela pública (art. 37 da CF) ou privada (art. 14 do CDC).

\subsection{O dever de indenizar dos pais dos agressores no bullying escolar e a jurisprudência.}

A jurisprudência pátria já se posicionou sobre o tema da responsabilidade dos pais pelos atos de bullying praticados por seus filhos menores, nos julgados adiante comentados.

Em maio de 2010, um juiz estadual, em Belo Horizonte (MG), condenou os pais de um agressor de bullying escolar a indenizar a família da vítima em $\mathrm{R} \$ 8.000,00$, absolvendo a escola ${ }^{91}$.

De acordo com o juiz, a vítima relatou que, em pouco tempo de convivência escolar, o agressor já começou a lhe colocar apelidos e fazer insinuações. Declarou que as incursões inconvenientes passaram a ser mais frequentes com o passar do tempo. Disse, ainda, que ela e seus pais chegaram a conversar na escola, mas não obtiveram resultados satisfatórios.

\footnotetext{
${ }^{91} 27^{\text {a }}$ Vara Cível de Belo Horizonte, Processo n 0 0024.08. 199172-1, Juiz Artur Rocha Hilário. Minas Gerais, 19 maio 2010.
} 
Além de indenização por danos morais, a estudante requereu a prestação, pela escola, de uma orientação pedagógica ao adolescente.

Para o magistrado, não se deve impor ao colégio a orientação pedagógica de aluno. Segundo ele, o exercício do poder familiar, do qual decorre a obrigação de educar, segundo o artigo 1.634, inciso I, do Código Civil, é atribuição dos pais ou tutores.

Em resposta às acusações, o representante do colégio declarou que todas as medidas consideradas pedagogicamente essenciais foram providenciadas.

Já os responsáveis pelo estudante agressor afirmaram que haveria uma conotação exagerada e fantasiosa em relação à situação vivenciada pelos menores. Salientaram que brincadeiras entre adolescentes não podem ser confundidas com a prática do bullying.

O magistrado esclareceu que a discussão envolvendo o bullying é peculiar e nova no âmbito judicial, com poucos litígios no Judiciário. Considerou que a prática é sintoma inerente ao próprio desenvolvimento e amadurecimento da sociedade pós-moderna.

De acordo com todo o conjunto de provas, o juiz considerou comprovada a existência do bullying. Segundo ele, o dano moral decorreu diretamente das atitudes inconvenientes do menor estudante, no intento de desprestigiar a estudante no ambiente colegial, com potencialidade de alcançar até mesmo o ambiente extracolegial.

Analisando as atitudes do estudante, o magistrado destacou que suas atitudes pareciam não ter limite, considerando que, mesmo após ser repreendido na escola, prosseguiu em seu modo de agir inconveniente voltado contra a estudante e contra outras alunas. De acordo o magistrado, as brincadeiras de mau gosto do estudante geraram problemas à colega e, 
consequentemente, seus pais devem ser responsabilizados, nos termos da lei civil.

Conforme a jurisprudência acima relatada, constata-se que o posicionamento do juízo foi no sentido de extrair a responsabilidade dos pais pela indenização devida em razão da prática de bullying por seu filho menor do exercício do poder familiar, do qual decorre a obrigação de educar, segundo o artigo 1.634, inciso I, do Código Civil, que é atribuição dos pais ou tutores.

Assim, nos casos em que as instituições, em especial as de iniciativa privada, convocam pais ou responsáveis em função de sinais de desajuste ou de agressividade dos menores sob sua guarda, no intuito de alertá-los e convocá-los a participar da solução do problema, sustenta a autora Ivana Leite que estes devem ser chamados a responder, solidariamente com a instituição de ensino, pela reparação dos danos causados por seus filhos, uma vez que estavam cientes do comportamento agressivo dos menores e se omitiram no dever de orientá-los.

Afinal, o Estatuto da Criança e do Adolescente (ECA), em seu artigo $4^{\circ}$, impõe primeiramente à família, embora não só à ela, o dever de zelar pelos direitos básicos do menor, dentre os quais destaca-se a educação. $\mathrm{O}$ mesmo Estatuto, no seu artigo $5^{\circ}$, impõe a proteção a crianças e adolescentes contra "qualquer forma de negligência", inserida, portanto, a negligência quanto à educação, especialmente tendo em vista que a referida lei impõe, expressamente, a observância dos "fins sociais a que ela se dirige, das exigências do bem comum e dos direitos e deveres individuais e coletivos."

Nesse sentido, defende Ivana Leite que, uma vez que fique evidenciada a desídia dos pais, devem eles, necessariamente, arcar com os prejuízos materiais e morais que dela decorram, sob pena de sobrecarregar- 
se os educadores e penalizar-se excessivamente a administração das escolas com uma responsabilidade que não é exclusiva sua.

Dessa forma, não obstante a responsabilização objetiva imputada às escolas, tanto públicas (art.37, CF), quanto privadas (art.14, CDC), haveria que se reconhecer a responsabilidade dos pais que venham sendo informados e advertidos de que seus filhos vêm demonstrando comportamento violento, intolerante e agressivo e não tomam nenhuma atitude para solucionar o problema, sendo pais e instituição de ensino corresponsáveis pela formação dos menores.

Nesse sentido, aduz a autora que, nos casos em que, comprovadamente, a escola tenha adotado todas as medidas consideradas pedagogicamente essenciais, inclusive convocado os pais à escola e exposto a eles a situação, não se deve imputar exclusivamente à instituição a responsabilidade pelos danos causados pelo aluno, ainda que o bullying tenha ocorrido nas dependências do estabelecimento escolar ${ }^{92}$.

Ora, não á dado aos pais isentar-se de sua obrigação legal de dirigir a educação e criação dos seus filhos, decorrente do exercício do poder familiar, transferindo-a integralmente às escolas, ficando em uma zona cômoda, imunes a qualquer tipo de responsabilização em razão de atos ilícitos praticados por seus filhos. Afinal, tal postura acaba por blindar os genitores de toda e qualquer responsabilidade, sob o argumento de que não se encontravam na companhia do menor, logo, não conheciam a situação de bullying protagonizada por seus filhos.

Logo, nos casos em que, comprovadamente, a escola tenha entrado em contato com os responsáveis e exposto a eles o envolvimento de seus filhos no bullying escolar, não há que se falar em isenção de responsabilidade dos pais, pois eles conheciam a situação e,

\footnotetext{
92 LEITE, Ivana. Bullying: a responsabilidade conjunta de pais e educadores na solução da violência infantojuvenil: Revista Visão Jurídica. São Paulo, n. 56, p. 69 - 75. 2011.
} 
conscientemente, preferiram fechar os olhos diante dela, adotando uma postura excessivamente permissiva com seus descendentes, sem buscar qualquer tipo de solução para a agressividade por eles demonstrada na escola.

O que caracteriza o bullying escolar é a prática contínua de agressões contra um estudante vítima, isto é, as agressões têm caráter repetitivo, de modo que o bullying é sempre uma situação que se estende no tempo. Assim, não é algo que se esgota em um único ato dirigido contra o aluno alvo, em um certo dia, e sim uma verdadeira perseguição voltada à vítima.

Dessa forma, é dever da escola notificar os pais dos envolvidos e expor a eles a situação de bullying, mas, uma vez que ela tenha feito isso, é evidente que os pais não poderão alegar que nada sabiam, ou que não têm responsabilidade sob o argumento de que, durante o cometimento das agressões por seus filhos, eles se encontravam na escola, razão pela qual a responsabilidade pelos atos deles seria transferida à instituição escolar.

Pois, em se tratando de agressões repetidas contra um mesmo aluno, ainda que elas sejam ambientadas na escola, não seria justo atribuir a responsabilidade exclusivamente à instituição escolar, sobretudo nos casos em que ela se mostra atenta ao seu dever de vigilância legalmente imposto e toma as providências julgadas pedagogicamente essenciais para solucionar o problema, inclusive notificando os responsáveis dos envolvidos para chamá-los a solucioná-lo.

Portanto, a análise das provas trazidas aos autos pelo magistrado é essencial, no sentido de averiguar a postura adotada tanto pela instituição de ensino quanto pelos pais diante de um caso de bullying evidenciado.

Se ficar comprovado que a escola adotou todas as providências cabíveis para solucionar o problema, estimulando o diálogo entre os envolvidos, aplicando advertências aos agressores, comunicando os pais destes sobre o envolvimento do seu filho na prática de bullying e, ainda 
assim, os responsáveis permaneceram inertes diante do problema, é o caso de responsabilizar solidariamente a instituição e os pais, diante da comprovada desídia destes, tendo em vista que a escola fez tudo o que estava ao seu alcance, não podendo, portanto, suportar a responsabilidade sozinha.

Como já demonstrado ao longo do presente trabalho, pais e instituição devem ser considerados corresponsáveis pela solução do fenômeno bullying, uma vez que a atuação de um deles, sem a colaboração do outro, torna-se inócua.

Assim, é dever da escola estar atenta ao comportamento de seus alunos e agir ao primeiro sinal de bullying praticado em suas dependências. Da mesma forma, devem os pais, uma vez que tomem conhecimento do envolvimento de seus filhos com a prática do bullying, procurar solucionar o problema, seja através do diálogo com o menor, a fim de entender as razões que o levam a agir de tal maneira, seja encaminhando-o para algum tratamento psicológico que se mostrar adequado.

O que não se pode endossar é que os pais ajam de forma excessivamente tolerante com seus filhos, ou façam vista grossa para a situação e, depois, aleguem que nada sabiam, procurando atribuir a responsabilidade pelos atos de seus filhos exclusivamente à instituição de ensino, amparando-se na intermitência de sua responsabilidade, que deixaria de existir enquanto os menores se encontram nas dependências do estabelecimento escolar.

Diante do exposto, revela-se acertado o posicionamento adotado pelo magistrado do julgado acima comentado, ao atribuir aos pais a responsabilidade pelos atos de bullying praticados por seu filho, uma vez que restou comprovado nos autos que a escola adotou todas as medidas consideradas pedagogicamente essenciais para solucionar a questão, enquanto os pais permaneceram inertes e, inclusive, buscaram 
descaracterizar a situação de bullying vivenciada pelos jovens, alegando que se tratava de brincadeiras normais e corriqueiras entre adolescentes.

Outro julgado do Tribunal de Justiça do Rio Grande do Sul, do ano de 2010, condenou a mãe de um menor praticante de atos de cyberbullying ao pagamento de indenização por danos morais no valor de $\mathrm{R} \$ 5.000,00^{93}$.

Segundo o TJRS, as fotos colacionadas aos autos, bem como o texto descrito na página da internet, evidenciaram ofensa de caráter moral indenizável. O filho da ré teria se apoderado de imagens colocadas na internet pelo autor e criado um fotolog, com intuito de humilhar o demandante, expondo fotos que teriam o condão de denegrir a honra da vítima. Não obstante, o agressor teria criado e-mail soucornoeadimito@bol.com.br - encaminhando mensagens ofensivas como “corno, viadinho, chifrudo...".

Assim, sustenta o julgado em análise que, ao lançar na rede mundial de computadores imagens depreciativas, com textos claramente de caráter pejorativo, o filho menor da ré teria ofendido os direitos de personalidade do autor, como a imagem e a honra.

Pela simples leitura dos fatos, bem como pela análise das provas colacionadas aos autos, entendeu o Tribunal restar incontroversa a ilicitude dos fatos praticados pelo descendente da demandada, configurando-se a prática de bullying. Ademais, esclarece o desembargador relator que, como, ao tempo das ofensas, o filho era menor de idade e estava sob a guarda e orientação da matriarca, esta é a responsável pelos atos do descendente, conforme prescreve o art. 932, I, do Código Civil.

Portanto, restando incontroversa a prática de bullying pelo filho menor sob a guarda da matriarca, estaria presente o dever de indenizar pelo

\footnotetext{
${ }^{93}$ TJRS, Apelação Cível no 70031750094, Rel. Desembargadora Liége Puricelli Pires. Rio Grande do Sul, 30 jun. 2010.
} 
dano moral suportado pela vítima, o qual, no caso, teria natureza in re ipsa $^{94}$.

Assim, ambos os julgados acima comentados revelam que os Tribunais têm entendido por responsabilizar os pais dos praticantes de bullying quando eles se revelam alheios à situação, permanecendo inertes diante do comportamento transgressor de seus filhos, fundamentando tal responsabilização tanto no exercício do poder familiar, do qual decorre a obrigação de educar os filhos e de dirigir-lhes a conduta, quanto na responsabilidade objetiva pelos atos dos filhos menores que estiverem sob sua guarda e autoridade.

\footnotetext{
${ }^{94}$ Esclarece o julgado: em outras palavras, o dano moral existe in re ipsa; deriva inexoravelmente do próprio fato ofensivo de tal modo que provada a ofensa, ipso facto está demonstrado o dano moral à guisa de uma presunção natural, uma presunção hominis ou facti, que decorre das regras da experiência comum. Provado que a vítima teve seu nome aviltado, ou a sua imagem vilipendiada, nada mais ser-lhe-á exigido provar, por isso que o dano moral está in re ipsa; decorre inexoravelmente da gravidade do próprio fato ofensivo, de sorte que, provado o fato, provado está o dano moral.
} 


\section{CONCLUSÃO}

O bullying escolar é, antes de tudo, uma forma específica de violência. Nesse sentido, deve ser identificado, reconhecido e tratado como um problema social complexo, cujo combate depende da atuação conjunta de diversos setores da sociedade.

Assim, a escola pode e deve representar um papel fundamental na redução desse fenômeno, tanto por meio de programas preventivos, uma vez que a profilaxia é sempre a melhor forma de evitar que o problema se instaure, quanto por meio de ações combativas nos casos de bullying já instalados.

Para tanto, é mister que a instituição escolar atue em parceria com as famílias dos alunos e com todos os setores que lutam pela redução da violência em nosso dia a dia.

O primeiro passo é o reconhecimento, por parte das escolas, da existência do bullying, bem como dos males que ele pode trazer para o desenvolvimento socioeducacional e para a estruturação da personalidade de seus estudantes. Afinal, o bullying é um fato e não se pode mais ignorar as evidências de sua propagação nos ambientes de ensino.

Ademais, é necessário que as instituições escolares capacitem seus profissionais para a identificação, o diagnóstico, a intervenção e o encaminhamento adequado dos casos ocorridos em suas dependências.

Por outro lado, é fundamental que os pais desenvolvam um canal aberto de diálogo com seus filhos, deixando-os à vontade para que possam compartilhar suas vivências, angústias, frustrações e expectativas. Somente dessa forma será possível que aqueles que são vitimados pelo bullying no ambiente escolar possam romper o silêncio e denunciar seus agressores para os responsáveis. 
Estudiosos do tema apontam que as soluções mais eficazes para o bullying ocorrem quando se estabelece uma parceria entre a escola, os pais dos jovens vítimas e os pais dos autores de maus-tratos.

No que se refere à responsabilização pelos atos de bullying praticados por menores no âmbito escolar que acarretem danos morais e materiais às vítimas, viu-se, ao longo do presente trabalho, que a responsabilidade poderá recair tanto nas instituições de ensino quanto nos pais que tiverem a guarda do menor agressor, conforme as circunstâncias de cada caso.

Se as agressões tiverem sido ambientadas nas dependências da instituição escolar, sem que a escola tenha adotado as medidas julgadas pedagogicamente necessárias para a solução do problema, tais como estimular o diálogo entre os envolvidos, aplicar advertências aos agressores e comunicar os pais destes sobre o envolvimento do seu filho na prática de bullying, a responsabilidade será suportada pela escola, seja ela pública ou privada, devendo a instituição arcar com eventuais indenizações a títulos de danos morais e materiais devidas às vítimas, por força tanto do disposto no artigo 932, IV, do Código Civil, quanto no que prescrevem o art. 37 da Constituição Federal e o art.14 do Código de Defesa do Consumidor.

Não obstante, se ficar evidenciado que, muito embora as agressões caracterizadoras do bullying escolar tenham ocorrido nas dependências do estabelecimento de ensino, os educadores adotaram uma postura compatível com o dever de vigilância que lhes é legalmente imposto, e fizeram tudo o que estava ao seu alcance para tentar solucionar o problema, inclusive convocando os pais à escola para debater a situação e pensar em soluções coletivamente, pensamos que a responsabilidade deverá ser suportada solidariamente pela instituição e pelos pais do menor, em razão da omissão destes no dever de orientar a conduta dos filhos que tinham sob sua autoridade e em sua companhia (art. 932, I, CC/02), decorrente do exercício do poder familiar, previsto no art.1634, I, do Código Civil. 
A análise é casuística e dependerá da valoração das provas dos autos pelo magistrado, que deverá investigar a postura adotada tanto pela instituição de ensino quanto pelos pais do menor diante de um caso de bullying que bata às portas do Poder Judiciário, a fim de chegar a uma conclusão sobre a quem imputar a responsabilidade pelos danos morais e materiais suportados pela vítima.

Portanto, a tese ora sustentada é no sentido de que pais e instituição de ensino devem ser responsabilizados solidariamente nos casos em que os genitores tenham sido alertados acerca do comportamento violento de seus filhos, causadores de danos físicos e psicológicos a outros menores, caracterizando-se o bullying escolar, e nada fizeram para solucionar o problema.

Se, por um lado, a escola assume a responsabilidade pelos atos praticados pelos menores enquanto estes estão dentro do estabelecimento escolar, por outro, compete aos pais o dever de educar e orientar os filhos, direcionando-lhes a conduta.

Dessa forma, muito embora os atos tipificados como bullying escolar sejam ambientados na escola, é certo que eles não se esgotam em um único episódio isolado; ao contrário, perfazem uma verdadeira perseguição protagonizada pelo agressor contra a vítima, em geral alguém que se diferencia dos demais por alguma característica, não se inserindo no grupo.

Ora, diante desse cenário, é função da escola mostrar-se atenta ao comportamento dos alunos durante o período em que estes se encontram sob a vigilância da instituição, de modo a inteirar-se de eventuais casos de bullying envolvendo seus educandos. Uma vez diagnosticado um caso de bullying, deve a escola convocar os pais dos menores envolvidos, notadamente os do menor agressor, a fim de que estes se inteirem da situação e possam colaborar na solução do problema. 
Entretanto, uma vez feito isso, é dever dos pais do agressor adotar uma postura efetivamente combativa em relação à conduta transgressora de seu filho, e não cruzar os braços e buscar imputar exclusivamente à instituição de ensino a responsabilidade pelo bullying escolar protagonizado pelo menor sob sua guarda.

Caso isso ocorra, deverão os pais ser chamados à responsabilização solidariamente com a instituição de ensino, em função da corresponsabilidade de ambos na tarefa de formar os menores.

Ademais, sendo modalidade de responsabilidade objetiva por fato de outrem, tanto dos pais (art. 932, I, CC/02), quanto das instituições de ensino públicas (art. 37, CF) e privadas (art.14, CDC), não há que provar-se a culpa in vigilando, bastando, apenas, a prova de que o menor se encontrava sob a autoridade e companhia dos pais, isto é, vivia sob o mesmo teto destes e de que fazia parte do corpo discente da instituição de ensino, sendo desnecessária a prova de que pais ou instituição tenham falhado no seu dever de vigilância do menor, pois esta prova supõe a análise de culpa.

Frise-se que, em se tratando de bullying ocorrido no âmbito de escolas públicas, existe o agravante de que a indenização imposta à instituição, ao final, é paga por toda a sociedade, o que reforça a tese de que deve haver responsabilidade solidária entre a escola e os pais do menor agressor.

O assunto ainda é muito incipiente no Poder Judiciário brasileiro, mas, a se julgar pelo atual grau de exposição do fenômeno bullying na mídia, é de se esperar que demandas versando sobre o tema "chovam" num futuro próximo.

Nada mais salutar, tendo em vista que a tomada de consciência da sociedade civil sobre o bullying é essencial no combate a essa prática nefasta, que já atinge quase o status de epidemia mundial. 
Nesse sentido, quanto mais informações sobre a questão forem divulgadas e debatidas, mais conscientes de seus direitos estarão os cidadãos, que poderão ingressar em Juízo para pleitear a reparação devida pelos agressores, o que, sem dúvida, irá coibir a prática de bullying.

Afinal, na sociedade capitalista em que vivemos, o órgão humano que mais traz preocupação aos indivíduos é o bolso, de modo que, se ele for afetado pelo arbitramento de indenizações a título de responsabilidade civil pelo Poder Judiciário, tanto os educadores, quanto os responsáveis, pensarão duas vezes antes de subestimar o problema e fazer vista grossa para a prática de bullying pelos menores sob sua guarda. 


\section{REFERÊNCIAS BIBLIOGRÁFICAS}

AGÊNCIA ESTADO. "Taxa de suicídio no Brasil sobe 17\% em 10 anos". Portal Ig. São Paulo, 24 fev. 2011. Disponível em <http://ultimosegundo.ig.com.br/brasil/taxa+de+suicidio+no+brasil+sobe+ 17+em+10+anos/n1238111374748.html> . Acesso em 12 abril 2011.

ALVES, Jeovanna Malena Viana. Responsabilidade civil dos pais pelos actos dos filhos menores. Rio de Janeiro: Renovar, 2004.

BAUMAN, Zygmunt. Vida para Consumo: a transformação das pessoas em mercadoria. Rio de Janeiro: Jorge Zahar Ed., 2008.

BEGALLI, Paulo Antonio. Responsabilidade civil dos pais por atos dos filhos menores. Rio de Janeiro: Forense, 2005.

BIRMAN, Joel. Ser ou não ser. Revista Cult. São Paulo, n. 157, p. 25 - 27, 2011.

CALHAU, Lélio Braga. Bullying: o que você precisa saber: identificação, prevenção e repressão. Niterói: Impetus, 2009.

CARVALHOSA, Susana. Prevenção da Violência e do Bullying em Contexto Escolar. Lisboa: Climepsi Editores, 2010.

CAVALIERI, Sergio Filho. Programa de responsabilidade civil. $8^{\text {a }}$ ed. São Paulo: Atlas, 2009.

CONSTANTINI, Alessandro. Bullying: como combatê-lo? São Paulo: Itália Nova Editora, 2004.

COTIDIANO. "Dirigentes de escolas têm dificuldade em avaliar casos de bullying”. Folha de São Paulo, São Paulo, p. c4, 02 maio 2011.

DIAS, José de Aguiar. Da responsabilidade civil. $11^{\text {a }}$ edição. Rio de Janeiro: Renovar, 2009.

FANTE, Cleo. Fenômeno Bullying: como prevenir a violência nas escolas e educar para a paz. $2^{\mathrm{a} e d}$. Campinas: Versus Editora, 2005.

FANTE, Cleo; PEDRA, José Augusto. Bullying Escolar: perguntas e respostas. Porto Alegre: Artmed, 2008.

FOLHA DE SÃO PAULO. "Só bullying não é capaz de explicar massacre no Rio”. São Paulo, 10 abril 2011. Disponível em <http://www1.folha.uol.com.br/cotidiano/900696-so-bullying-nao-e-capazde-explicar-massacre-no-rio.shtml>. Acesso em 11 abril 2011. 
FOLHA DE SÃO PAULO. "Descobrirão quem eu sou da maneira mais radical". São Paulo, 13 abril 2011. Disponível em

<http://www1.folha.uol.com.br/cotidiano/902211-descobrirao-quem-eusou-da-maneira-mais-radical-diz-atirador.shtml> . Acesso em 16 abril 2011.

GONÇALVES, Carlos Roberto. Responsabilidade Civil. $8^{\mathrm{a}} \mathrm{ed}$. Rio de Janeiro: Saraiva, 2009.

GUARESCHI, Pedrinho; SILVA, Michele. Bullying: mais sério do que se imagina. Porto Alegre: Artmed, 2008.

LEITE, Ivana. Bullying: a responsabilidade conjunta de pais e educadores na solução da violência infantojuvenil. Revista Visão Jurídica. São Paulo, n. 56, p. 69- 75, 2011.

LIMA, Alvino. A responsabilidade civil pelo fato de outrem. Rio de Janeiro: Forense, 1973.

MIDDELTON, Jane; ZAWADSKI, Mary. Bullying: Estratégias de sobrevivência para crianças e adultos. Porto Alegre: Artmed, 2007.

OCHBERG, Frank. A escola ainda é um lugar seguro. $O$ Globo, Rio de Janeiro, p.13, 10 abril 2011.

O GLOBO. "Wellington Menezes era vítima de 'bullying' nos tempos da escola”. Rio de Janeiro, 08 abril 2011. Disponível em <http://oglobo.globo.com/rio/mat/2011/04/07/wellington-menezes-eravitima-de-bullying-nos-tempos-da-escola-924190244.asp >. Acesso em 10 abril 2011.

O GLOBO. "Lei torna obrigatória notificação de casos de bullying no Rio". Rio de Janeiro, 23 setembro 2010. Disponível em <http://oglobo.globo.com/rio/mat/2010/09/23/lei-torna-obrigatorianotificacao-de-casos-de-bullying-no-rio-921059514.asp>. Acesso em 12 abril 2011.

O GLOBO. "Apesar de lei determinar, escolas não notificam casos de bullying em conselhos tutelares ou na polícia". Rio de Janeiro, 16 abril 2011. Disponível em <http://oglobo.globo.com/rio/mat/2011/04/16/apesarde-lei-determinar-escolas-nao-notificam-casos-de-bullying-em-conselhostutelares-ou-na-policia-924258087.asp>. Acesso em 17 abril 2011.

O GLOBO. "Belo Horizonte faz lei para combater bullying". Rio de Janeiro, 13 maio 2011. Disponível em <http://oglobo.globo.com/educacao/mat/2011/05/13/belo-horizonte-faz-leipara-combater-bullying-924451021.asp>. Acesso em 14 maio 2011.

O GLOBO. "Bullying já afeta 84,5\% dos estudantes no Rio. Mais de 40\% já foram vítimas”. Rio de Janeiro, 17 abril 2011. Disponível em 
<http://oglobo.globo.com/rio/mat/2011/04/17/bullying-ja-afeta-84-5-dosestudantes-no-rio-mais-de-40-ja-foram-vitimas-924263992.asp>. Acesso em 18 abril 2011.

O GLOBO. "Gente que sofreu ou praticou bullying ensina como dar a volta por cima". Rio de Janeiro, 10 maio 2011. Disponível em <http://oglobo.globo.com/educacao/mat/2011/05/09/palestra-criada-porgente-que-sofreu-ou-praticou-bullying-ensina-como-dar-volta-por-cima924421469.asp>. Acesso em 10 maio 2011.

PAOLA, Fernanda. Anjos vingadores. Revista Cult. São Paulo, n. 157, p. 28 - 29, 2011.

PAULA, Carmen de. Bullying nas escolas. Rio de Janeiro: Pajú Editora, 2008.

PEREIRA, Caio Mário da Silva. Responsabilidade civil. 9a ed. Rio de Janeiro: Forense, 1998.

RODRIGUES, Silvio. Direito Civil. 12a ed. São Paulo: Saraiva, 1989.

SILVA, Ana Beatriz Barbosa. Bullying: mentes perigosas nas escolas. Rio de Janeiro: Objetiva, 2010.

STOCO, Rui. Responsabilidade Civil e sua interpretação Jurisprudencial. $3^{\mathrm{a}}$ ed. Rio de Janeiro: Editora Revista dos Tribunais, 1997.

\section{Sítios visitados}

ABRAPIA: Associação Brasileira Multiprofissional de Proteção à Infância e à Adolescência. Disponível em <http://www.abrapia.org.br>. Acesso em 11 abril 2011.

APRENDER SEM MEDO. Disponível em $<\mathrm{http} / /$ :www.aprendersemmedo.org.br/doc/pesquisa_plan_relatorio_final. pdf.>. Acesso em 03 maio 2011.

Disponível em <http://www.aprendersemmedo.org.br/?p=faca-o-teste>. Acesso em 03 maio 2011.

BBC BRASIL. Disponível em <http://www.bbc.co.uk/portuguese/reporterbbc/story/2007/04/070419_mata dormensagemg.shtml>. Acesso em 06 abril 2011. 
CONSULTOR JURÍDICO. Disponível em <http://www.conjur.com.br/2011-mai-29/falta-lei-justica-quem-decidebullying>. Acesso em 30 maio 2011.

OBSERVATÓRIO DA INFÂNCIA. Disponível em

<http://www.observatoriodainfancia.com.br/article.php3?id_article=232 > Acesso em 12 abril 2011.

PROGRAMA ANTI-BULLYING - EDUCAR PARA A PAZ. Disponível em<http://www.bullying.pro.br/index.php?option=com_content\&view=arti cle\&id=75>. Acesso em 08 maio 2011.

SAFERNET BRASIL. Disponível em <http://www.safernet.org.br/site>. Acesso em 05 maio 2011.

WIKIPEDIA. Disponível em <http://pt.wikipedia.org/wiki/bullying > Acesso em 11 abril 2011.

YOUTUBE. $<$ http://www.youtube.com/watch? $\mathrm{v}=\mathrm{wdd} 3 \mathrm{EK} 4 \mathrm{wFdQ} \&$ feature $=$ fvst $>$. Acesso em 15 abril 2011.

<http://www $. y o u t u b e . c o m / w a t c h ? v=0 X T Z 8 Q 7 d q R M>$. Acesso em 01 abril 2011. <http://www.youtube.com/watch?v=JCejbz22y2w>. .Acesso em 01 abril 2011.

Jurisprudência

$27^{\mathrm{a}}$ Vara Cível de Belo Horizonte, Processo n ${ }^{\circ}$ 0024.08. 199172-1, Juiz Artur Rocha Hilário. Minas Gerais, 19 maio 2010.

TJDFT, Apelação Cível no 20060310083312, Rel. Desembargador Waldir Leôncio Júnior. Brasília, 09 jul. 2008.

TJMG, Apelação Cível no 1.0024.05.890294-1/001(1), Rel. Desembargador Tarcísio Martins Costa. Minas Gerais, 10 abril 2007.

TJRJ, Apelação Cível nº 0003372-37.2005.8.19.0208, Rel. Desembargador Ademir Paulo Pimentel. Rio de Janeiro, 02 fev. 2011

TJRJ, Apelação Cível n 0015239-71.2007.8.19.0203, Rel. Desembargador Carlos Eduardo da Fonseca Passos. Rio de Janeiro, 28 jul. 2010. 
TJRS, Apelação Cível no 70031750094 , Rel. Desembargadora Liége Puricelli Pires. Rio Grande do Sul, 30 jun. 2010

TJRS, Apelação Reexame necessário no 70019324268 , Rel. Desembargador Odone Sanguiné. Rio Grande do Sul, 04 dez. 2007. 
A presente Monografia, apresentada pela aluna MUSA MÁXIMO GOMES FERRAZ, poderá ser submetida à exposição e defesa perante a Banca Examinadora designada pelo Departamento de Direito da PUC-Rio.

Rio de Janeiro, de de 2011.

Caitlin Sampaio Mulholland

Assinatura da professora orientadora

A autora deste trabalho autoriza o Departamento de Direito da PUC-Rio a divulgá-lo, no todo ou em parte, resguardados os direitos autorais conforme legislação vigente.

Rio de Janeiro, de 2011.

Assinatura da aluna 